\title{
Ankara'daki Halk Kütüphanesi Çocuk Bölümleri ve Çocuk Kütüphanelerinin Bina, Güvenlik Donanımı ve Malzeme Niteliklerinin İncelenmesi
}

\section{Investigation of Building, Security Equipment and Material Qualifications of Public Library Children's Departments and Children's Libraries in Ankara}

\author{
Arif Yılmaz*iD), Nilay Kaptan**(D) ve Ayşenur Ulusoy Ünlü**(iD
}

$\ddot{O} z$

Amaç: Kütüphane bilinci, çocukların kütüphanelere erken yaşta gelmesi ile kazanılabilir. Bu süreçte kütüphanelerin hizmetlerini okul öncesi dönem çocuklarına ve ailelerine yönelik gerçekleştirmesinde sunulan hizmetler için gerekli mekânların varliğl ve niteliği büyük önem taşımaktadır. Bu çalışmanın amacı; Ankara'da bulunan çocuk kütüphaneleri ile il ve ilçe halk kütüphanelerinin çocuk bölümlerinin bina, güvenlik donanımı ve malzeme özelliklerini inceleyerek ne tür niteliğe sahip olduklarını ortaya çıkarmaktır. Yöntem: Bu çalışmanın örneklemini amaçlı örnekleme yöntemi ile seçilen ve Ankara ilinde bulunan bir il halk kütüphanesi, bir çocuk kütüphanesi ve beş ilçe halk kütüphanesi oluşturmaktadır. Araştırmada nicel araştırma yöntemlerinden tarama modeli kullanılmış olup araştırmanın verileri araştırmacılar tarafindan geliştirilen "Çocuk Kütüphaneleri Fiziksel Durum Kontrol Listesi" aracılığı ile toplanmıştır. Bulgular: Yapılan bu araştırmanın sonuçlarına göre bina özellikleri bakımından 24 maddenin 19'una (\%79) sahip olan Ankara Ali Dayı Çocuk Kütüphanesi bina niteliği en yüksek kütüphane olurken, 24 maddenin 6'sına (\%25) sahip olan Cebeci İlçe Halk Kütüphanesi ise bina niteliği en düşük kütüphane olarak saptanmıştır. Güvenlik donanım bakımından yine Ankara Ali Dayı Çocuk Kütüphanesi 17 maddenin 11'inden (\%65) "Evet" alarak seçilen kütüphaneler arasında en iyi güvenlik donanımına sahip durumdayken Cebeci, Mamak ve Sincan Illçe Halk Kütüphanelerinin ise maddelerin yalnızca 4'ünden (\%24) "Evet" sonucu alarak güvenlik donanımı bakımından en alt sirada oldukları görülmüştür. Malzeme bakımından ise Ankara Ali Dayı Çocuk Kütüphanesi ve Keçiören Cemil Meriç Illçe Halk Kütüphanesi 19 maddenin 16'sindan (\%84) "Evet” sonucu alarak sahip olunan malzeme

\footnotetext{
${ }^{*}$ Hacettepe Üniversitesi, Eğitim Fakültesi Temel Eğitim Bölümü, Ankara, Türkiye. E-posta: arif@hacettepe.edu.tr

Hacettepe University, Department of Early Childhood Education, Ankara, Turkey. E-mail: arif@hacettepe.edu.tr

*** Anadolu Üniversitesi, Eğitim Fakültesi Temel Eğitim Bölümü, Eskişehir, Türkiye. E-posta:

nilaykaptan@anadolu.edu.tr

Anadolu University, Department of Early Childhood Education, Eskişehir, Turkey. E-mail:

nilaykaptan@anadolu.edu.tr

**** Hacettepe Üniversitesi, Eğitim Fakültesi Temel Eğitim Bölümü, Ankara, Türkiye. E-posta:

aysenurulusoy@ hacettepe.edu.tr

Hacettepe University, Department of Early Childhood Education, Ankara, Turkey. E-mail:

aysenurulusoy@hacettepe.edu.tr
}

Geliş Tarihi - Received: 02.05 .2021

Kabul Tarihi - Accepted: 22.09.2021

Yayımlanma Tarihi - Published: 30.09.2021 
Ankara’daki Halk Kütüphanesi Çocuk Bölümleri ve Çocuk Kütüphanelerinin Bina, Güvenlik Donanımı ve Malzeme Niteliklerinin İncelenmesi

Investigation of Building, Security Equipment and Material Qualifications of Public Library Children's Departments and Children's Libraries in Ankara

niteliği bakımından en üst, Altındă̆ İlçe Halk Kütüphanesi ise 9 maddeden (\%47) "Evet" sonucu olarak seçilen kütüphaneler arasında en alt basamaktadır. Sonuç: Çalışmanın sonucunda ortaya çıkan bulgular genel fiziksel durum açısından değerlendirildiğinde, örneklem grubunda yer alan yedi kütüphanenin ikisinin iyi niteliklere sahip, üç kütüphanenin ortalama nitelikte ve iki kütüphanenin ise yetersiz niteliklere sahip olduğunu göstermektedir. Özgünlük: Bu çalışma araştırmacılar tarafindan geliştirilen "Çocuk Kütüphaneleri Fiziksel Durum Kontrol Listesi” kullanılarak Ankara'da farklı kütüphanelerde gerçekleştirilmiş ve araştırmacılar rehber kişi eşliği olmadan objektif bir şekilde kütüphanelerin fiziksel durumların yerinde incelemiştir.

Anahtar Sözcükler: Çocuk kütüphaneleri; çocuk bölümleri; fiziksel durum; bina özellikleri; güvenlik donanımı; malzeme; kontrol listesi.

\section{Abstract}

Objective: Library awareness can be gained by children when they come to the library at an early age. In this process, the existence and quality of the spaces required for the services provided has a great importance for libraries to realize their services for preschool children and their families. The aim of this study is to examine the children's libraries and children's departments in Ankara Province and to reveal their quality in context of their building, security equipment and material properties. Method: The sample of this study consists of 1 provincial public library, 1 children's library and 5 district public libraries in Ankara, which were selected by purposeful sampling method. The survey research, one of the quantitative research methods, was used in the study, and the data of the research were collected through the "Children's Libraries Physical Condition Checklist" developed by the researchers. Findings: According to the results of this research, Ankara Ali Dayl Children's Library, which has 19 (79\%) of the 24 items in terms of building characteristics, is the library with the highest building quality, while Cebeci District Public Library, which has 6 of 24 items (25\%), has been determined as the library with lowest building quality. In terms of security equipment, while Ankara Ali Dayl Children's Library has the best security equipment among the libraries selected with a "Yes" result from 11 (\%65) of 17 items; Cebeci, Mamak and Sincan District Public Libraries, on the other hand, received only "Yes" from 4 (\%24) of the items and they were in the lowest place in terms of security equipmnet. In terms of materials, Ankara Ali Dayl Children's Library and Keçiören Cemil Meriç District Public Library received a "Yes" result from 16 (\%84) of the 19 items and has the highest material quality; Altındağ District Public Library is at the lowest level among libraries selected with a "Yes" result from 9 (\%47) items. Results: According to the findings of the study, it was found that two of the seven libraries in the sample group were in good condition, three libraries were in average characteristics, and two libraries were in insufficient characteristics in terms of general physical condition. Originality: This study was carried out using the "Library Physical Condition Checklist" developed by the researchers, was carried out in different libraries in Ankara province, and the researchers objectively examined the physical conditions of the libraries without guidance. 
Keywords: Children's libraries; children's departments, physical condition; building features; security equipment; material; control list.

\section{Giriş}

Kütüphaneler, toplumun bir araya gelmesini ve sosyalleşmesini sağlayan, kentin temel hafızalarıdır. Bir toplumun kalitesi, genellikle içerisinde bulunan çocukların yaşam kalitesine bağlıdır (Sullivan, 2005, s. 8). Çocukların yaşam kalitelerini artıran önemli unsurlardan biri ise çocuk kütüphaneleridir. Bir kütüphane türü olarak çocuk kütüphanesi, "çocuğun temel yaşam becerilerini elde etmede belirleyici bir rol oynayan, kütüphane kültürünü başlatan, doğru bilgiye erişimini sağlayan, okuma kültürünü, eğitimini, kültürel gelişimini, olumlu kişilik özellikleri geliştirme ve toplumsallaştırma sürecini destekleyen güvenilir bir kuruluştur” (Yılmaz, 2019, s. 11). Çocuklara yönelik nitelikli bir kütüphane için hem çocuk hem ebeveyn ve nihayetinde toplum açısından birçok faydadan söz etmek mümkündür (Shine Edizer ve Akçay Duff, 2019, s. 16).

Yapılan araştırmalar nitelikli çocuk kütüphanelerinin veya halk kütüphanelerinin çocuk bölümlerinin, çocukların erken okuryazarlık becerilerini desteklediğini (Cevher, 2015; Fasick ve Edmonds, 2013; Goulding, Dickie ve Shuker, 2017; International Federation of Library Associations and Institutions [IFLA], 2007; Kipfer, 2019; Kupetz, 1993), onların zihinsel (Stevens, 1999) ve sosyal gelişimine katkı sağladığını (Ozanne ve Ozanne, 2011; Miller, Zickuhr, Rainie ve Purcell, 2013), ayrıca çocuklara kütüphane teknolojileri ve kaynaklarına ilişkin bilgi sağladığını ve onlara sorularını kütüphane vasıtasıyla cevaplandırmaları için gerekli olan bilinci kazandırdığını göstermektedir (IFLA, 2009). Kütüphaneler aynı zamanda çocukları topluma kazandırmanın güvenli yollarından biridir (IFLA, 2011). Bu yolda kütüphaneler, hem çocuklar ve ailelerine yönelik kaynak ve hizmet erişimi sağlamakta (Fasick ve Edmonds, 2013, s. 4) hem de ailelere çocukları ile etkileşim kurmasını sağlayacak yeni yollar sunmaktadır (Kipfer, 2019, s. 3). Bu bağlamda ailelere hem kendi kullanabileceği hem de çocuklarının eğlenip öğreneceği mekânlar sunan kütüphane binalarının toplumsal kültüre yapacağı katkı göz ardı edilemeyecek kadar önemlidir (Küçükcan, 2010 s. 58).

Kütüphanelerin; bütçe, personel, bina, koleksiyon gibi yapısal öğelerini çevresel koşullarda incelemek ve uluslararası standartlar ile karşılaştırmak kütüphane hizmetlerinin başarılı olması için atılması gereken ilk adımdır (Çakın, Ersoy, Çelik ve Duman, 1993). Kütüphaneyi oluşturan unsurları bir araya getiren bir mekân (Küçükcan, 2010, s. 55) ve yapısal unsurlardan biri olan kaliteli bir kütüphane binası ise insanların ev ve iş yerlerinden sonra günlük hayatlarında kullanmaları beklenen "üçüncü mekân" olarak nitelendirilmektedir (Kütüphaneler ve Yayımlar Genel Müdürlüğü [KYGM], 2017b, s. 9). Bu üçüncü mekândan tasarım olarak beklenti; çocukların, gençlerin, yetişkinlerin ve yaşlıların kütüphane içerisinde öğrenme, eğlenme ve dinlenme ihtiyaçlarını karşılayabilecekleri bir sosyal iletişim mekânı olması (KYGM, 2017b, s. 5) ve bunun yanında yeni gelişen teknolojiler ile kitap arasında uyumu sağlamasıdır (Keseroğlu, 2010, s. 50). Ayrıca çocuklar için kütüphaneler, çocuğun aktif katılımına olanak veren, özgür deneyimi teşvik eden, yaparak/yaşayarak öğrenme fırsatı sunan, motivasyonu artıran, heyecanlı ve eğlenceli metodun kütüphane mekânına yansımasını sağlayan, statik ve durağan bir kurgudan dinamik ve etkileşimli bir yapıya dönüşen binalar 
Ankara'daki Halk Kütüphanesi Çocuk Bölümleri ve Çocuk Kütüphanelerinin Bina, Güvenlik Donanımı ve Malzeme Niteliklerinin İncelenmesi

Investigation of Building, Security Equipment and Material Qualifications of Public Library Children's Departments and Children's Libraries in Ankara

olarak tasarlanmalı (Potur, 2010, s. 75) ve tasarlanan kütüphane binalarının çocuklar için sıcak bir ortam olmasına özen gösterilmelidir (Bradfield, 2011, s. 17).

Nitelikli bir çocuk kütüphanesi binasının taşıması gereken bazı özellik ve ilkeler vardır. Çocuk kütüphanesi binasının dış mekân özelliklerine ilişkin çalışmalara göre kütüphaneler; merkezi konumda olmalı, çevrenin iklim özelliklerine uygun yalıtıma sahip olmalı, ısı kontrolü ve nem oranı standartlara uygun olmalı, yapı malzemesi estetik ve dayanıklı olmalı, eğer olanaklı ise binaya merdivensiz ulaşım sağlanmalı (Yılmaz, 2019, s. 21) ve eğer çok merdivenli bir bina ise asansörü olmalıdır (IFLA, 2007, s. 7). Ayrıca engelli kullanıcıların kütüphane hizmetlerine tam olarak ulaşmasını sağlayacak şekilde bina tasarımı gerçekleştirilmeli ve kullanıcıların ihtiyaçlarını karşılayacak kafeteryaya yer vermelidir (Yılmaz, 2019, ss. 22-23). Ayrıca çocuk kütüphanelerinin iç ve dış mekânlarında çocuklar için oyun alanları bulunmalıdır (KYGM, 2017b, s. 12).

Diğer taraftan çocuk kütüphanelerinin taşıması gereken bazı iç mekân özellikleri ve ilkeleri vardır. Ulusal ve uluslararası çalışmalara göre; çocuk kütüphanesi binasının zemini çocuklar için uygun olmalı (KYGM, 2017a, s. 40; KYGM, 2017b, s. 12; Y1lmaz, 2019, s. 117), kütüphane; çocuk bakımı için ayrılmış bir yere sahip olmalı, doğal ve yapay olarak yeterli ışığa sahip olmalı, alan ve mobilyalar çocukların güvenlikleri dikkate alınarak yerleştirilmeli (IFLA, 2018, s. 18), mobilya ve rafların kenarları keskin olmamalı ve elektrik prizlerinin üzeri kapalı olmalıdır (IFLA, 2007, s. 8). Ayrıca Çocuk Kütüphaneleri Çalıştayına (KYGM, 2017a) göre, çocuk kütüphanesinde iç mekâna ilişkin tasarım yapılırken çocukların psikolojisine uygun, dikkat çekici, eğlenceli mekânlar tasarlanmasına özen gösterilmeli, kullanılan malzeme ve materyalin çocuk sağlı̆̆ına uygun olmasına dikkat edilmelidir.

Nitelikli çocuk kütüphanesinin taşıması gereken özellikler göz önünde bulundurulduğunda her kütüphanenin, elinde bulundurduğu malzemenin bakımını yapabilmek için kuruluşun ve koleksiyonların fiziki durumu ile onların korunma gereksinimlerinin kapsamlı ve güvenilir bir değerlendirmesini yapmasının gerekliliği ortaya çıkmaktadır (Adcock, 2011, s. 14). Toplumun kültürel/bilgisel lokomotifi olan halk kütüphaneleri, kullanıcıların istek, ihtiyaç ve beklentileri doğrultusunda kavramsal, düşünsel ve mekânsal olarak yeniden düzenlenmelidir (KYGM, 2017b). Bu düzenlemeler elbette ki alandaki bilimsel araştırmalar temel alınarak yapılmalı ve kütüphaneler diğer bilim dalları ve disiplinleriyle birlikte çalışmalıdır. Türkiye'de çocuk kütüphaneleri özellikle son yıllarda, Kütüphaneler ve Yayımlar Genel Müdürlüğünün (KYGM) öncelik verdiği çalışma konularından biri haline gelmiştir. Özellikle çocukların kütüphanelerden beklentilerini ifade ettikleri "Hayalimdeki Kütüphane Araştırması" konunun tüm paydaşlarını bir araya getiren "Çocuk Kütüphaneleri Çalıştayı” çocuk ve gençlik yayıncılığının ve okuma kültürünün detaylandırıldığı “6. Ulusal Yayın Kongresi” ile konuya ilişkin akademik ve pratik farkındalığın artırılması ve çocuk kütüphaneciliğinin ülke gündemine taşınması amaçlanmıştır (Aldemir, 2018, s. 34).

Gerek erken çocukluk eğitiminin öneminin kavranması gerekse çocuk kütüphanelerinin çocukların eğitimi ve gelişimi için önemli bir role sahip olduğunun anlaşılması, çocuk kütüphanelerine yönelik akademik çalışmaları arttırmıştır (Cevher, 2015; Gönen, Temiz ve Akbaş, 2015; Delice Güller ve Bilbay, 2016; Kakırman Yıldız, Yalçınkaya ve Saydam, 2018; 
Mills, Romeign Stout, Campbell ve Koester, 2015; Y1lmaz, 2008). İstanbul'un farkl1 bölgesindeki 30 halk kütüphanesinin çocuk bölümünde okul öncesi dönem çocukları için ayrılmış olan alanların uygunluk durumunu değerlendiren Kakırman Yıldız, Yalçınkaya ve Saydam'a (2018, s. 1833) göre incelenen binaların mimari tasarımı kullanıcı ihtiyaç ve beklentisinden hayli uzaktır. Delice Güller ve Bilbay (2016, s. 411) ise kütüphane yapılarında okul öncesi dönemdeki çocuklara yönelik interaktif mekânları incelediği çalışmasında mekân tasarımı ve mekânın interaktif olmasının önemini vurgulamaktadır. Ayrıca İstanbul'daki halk ve çocuk kütüphanelerini iç ve dış mekân açısından inceleyen Saydam ve Sağlık (2015, s. 73) çalışması sonunda yeni binaya sahip olması ve konumu değişmesi gereken kütüphaneler olduğu sonucuna ulaşmıştır. Görülmektedir ki çocuk kütüphanelerine ilişkin alanda daha fazla analiz etme, değerlendirme ve iyileştirmeye yönelik çalışmalara ihtiyaç vardır.

Ayrıca çocuk kütüphaneleri ile ilgili çalışmaların çoğunlukla Kütüphanecilik / Bilgi ve Belge Yönetimi alanında yapıldığı görülmektedir. Çocuk kütüphaneleri mimarisi ve iç mekân tasarımı alanında yapılan akademik çalışmaların az olduğu; fakat son yıllarda çocuk odaklı mekân tasarımının ve çocuk kütüphaneleriyle ilgili çalışmaların artmaya başladığı görülmektedir (Bossaller, Oprean, Urban ve Riedel, 2020; Burkut, 2018; Pivik, 2010; Yavuz Öden, 2021). Örneğin, Yavuz Öden (2021, s. 101) çocuk kütüphanelerinin iç mekân tasarımında mobilya kullanımına ilişkin gerçekleştirdiği çalışmasında, kütüphanelerde kullanılan çok fonksiyonlu elemanların biçimsel ve fonksiyonel özelliklerinin önemine dikkat çekmiştir. Ancak çocuk kütüphanesine ilişkin çalışmaların çok alanlı tabanda yapılması, hem farklı disiplinlerin bakış açılarının bir araya gelmesine olanak tanıyacak, hem de daha kapsamlı bir değerlendirme yapma firsatı sağlayacaktır. $\mathrm{Bu}$ nedenle yapılan çalışmanın kontrol listesi oluşturulurken; mimar, inşaat mühendisi, kütüphaneci ve okul öncesi uzmanı olmak üzere farklı alan uzmanlarından görüş alınmıştır. Ayrıca daha iyi bir kütüphane hizmeti için, kütüphanelerin ulusal ve uluslararası standartlarda değerlendirilmesi gerekmektedir (Çakın, Ersoy, Çelik ve Duman, 1993, s. 222). Bu çalışmada çocuk kütüphanelerine ilişkin ulusal (KYGM, 2017a; KYGM, 2017b) ve uluslararası (IFLA, 2003; IFLA, 2007; IFLA, 2018) ilke ve özellikler temel alınarak, Ankara'da hizmet veren halk kütüphanelerinin çocuk bölümleri ve çocuk kütüphanelerinin bina, güvenlik donanımı ve materyal özelliklerini analiz etmek ve bu kütüphanelere ulusal ve uluslararası standartlar doğrultusunda öneri sunmak amaçlanmaktadır.

\section{Yöntem}

Bir araştırma yönteminin seçilmesi; araştırmacının amacı, cevaplanacak araştırma soruları ve kaynakların kullanılabilirliği gibi birçok faktöre bağlı olarak gerçekleşir (Sezgin Selçuk, 2018, s. 140). Çalışmada araştırmacılar tarafından, incelenen çocuk kütüphanelerinin bina özelliği (asansör, lavabo, otopark vb.), güvenlik donanımı (1sıtıcılar, yangın tüpü, ilk yardım seti vb.) ve malzeme özellikleri (ödünç alma masası, raf, ilan panosu vb.) hakkında bilgi toplanmış ve toplanan bilgiler kullanılarak çocuk kütüphanelerinin mevcut durumunun betimlemesi yapılmıştır. $\mathrm{Bu}$ bağlamda araştırma sorusu; "Ankara'daki halk kütüphanelerinin çocuk bölümleri ve çocuk kütüphanelerinin bina, güvenlik donanımı ve malzeme özellikleri nasıldır?” olarak belirlenmiştir. Araştırmanın hipotezi ise "Ankara'daki halk kütüphanelerinin çocuk bölümleri ve çocuk kütüphanelerinin bina, güvenlik donanımı ve malzeme özellikleri yeterlidir.” şeklinde belirlenmiştir. 
Ankara'daki Halk Kütüphanesi Çocuk Bölümleri ve Çocuk Kütüphanelerinin Bina, Güvenlik Donanımı ve Malzeme Niteliklerinin İncelenmesi

Investigation of Building, Security Equipment and Material Qualifications of Public Library Children's Departments and Children's Libraries in Ankara

$\mathrm{Bu}$ çalışma betimsel bir araştırma olup tarama modeli kullanılarak gerçekleştirilmiştir. Betimsel araştırma, belirli olayları tipik olarak tek bir zamanda gözlemlemeyi (hakkında bilgi toplamayı) amaçlayan en temel araştırma türüdür (Kelley, Clark, Brown ve Sitzia, 2003, s. 261). Betimsel araştırmanın en yaygın türü tarama araştırmalarıdır (Koh ve Owen, 2000, s. 220). Tarama araştırmaları, önceden belirlenmiş bir popülasyondaki değişkenlerin sıklı̆̆ı, dağılımı ve aralarındaki ilişkiler hakkında bilgi toplamak için kullanılan deneysel olmayan bir araştırma yaklaşımıdır (Coughlan, Cronin ve Ryan, 2009, s. 9). Bu yaklaşımın en önemli özelliklerinden biri örneklemin bazı yönlerini ve özelliklerini (yetenek, inanç, görüş, tutum ve/veya bilgi gibi) tanımlamak için bilgi toplanmasıdır (Fraenkel, Wallen ve Hyun, 2012, s. 393).

\section{Örneklem}

Tarama araştırmalarında analiz birimleri (örneklem) genelde insanlar olsa da nesneler, kulüpler, şirketler, sınıflar, okullar, devlet kurumları ve diğer şeyler olabilir (Fraenkel, Wallen ve Hyun, 2012, s. 395). Burada örnekleme karar verirken dikkat edilmesi gereken gerçekçi hedefler koymak olmalıdır. Cohen, Manion ve Morrison'a (2000, s. 92) göre maliyet, zaman ve erişilebilirlik faktörleri nedeniyle bir örneklemden ölçüm almak her zaman pratik ve mümkün değildir. Çalışmada kullanılan amaçlı örnekleme yöntemi maliyet, zaman ve erişilebilirlik faktörleri dikkate alınarak seçilmiştir. Amaçlı örnekleme araştırmacının önceki kişisel bilgilerinin yönlendirmesiyle evreni temsil edeceğini düşündüğü bir örneklem seçmesidir (Fraenkel, Wallen ve Hyun, 2012, s. 100). Bu şekilde araştırmacılar özel ihtiyaçları doğrultusunda tatmin edici bir örneklem oluşturabilir (Cohen, Manion ve Morrison, 2000, s. 103). Bu araştırmada Ankara İl Kültür ve Turizm Müdürlüguüne bağlı 43 halk kütüphanesi ve 1 çocuk kütüphanesi arasından 6 çocuk bölümü ve 1 çocuk kütüphanesi seçilmiştir. Bu kütüphaneler farklı merkez ilçelerde yer alması ve farklı sosyoekonomik düzeyden gelen çocuklara hizmet veriyor olması bakımından önem teşkil etmektedir. Bu bağlamda amaçlı örnekleme yöntemi ile seçilen Ankara Adnan Ötüken İl Halk Kütüphanesi, Ankara Ali Dayı Çocuk Kütüphanesi, Altındağ İlçe Halk Kütüphanesi, Cebeci Halk Kütüphanesi, Keçiören Cemil Meriç İlçe Halk Kütüphanesi, Mamak İlçe Halk Kütüphanesi ve Sincan İlçe Halk Kütüphanesi olmak üzere Ankara ilinde bulunan bir il halk kütüphanesi ile bir bağımsız çocuk kütüphanesi ve beş ilçe halk kütüphanesi çocuk bölümü çalışmanın örneklemini oluşturmaktadır.

Örneklem dâhilinde ele alınan kütüphanelerden biri olan Ankara Adnan Ötüken İl Halk Kütüphanesinin açılışı 26 Temmuz 1922 tarihli Hâkimiyet-i Milliye gazetesinde "Maarif Umumi Kütüphanesi" adı ile halka bildirilmiş̧tir. 1939 yılında Ulus bölgesinde koleksiyonu büyümeye başlayan kütüphane, 1983 yllında Kumrular Caddesi'ndeki hizmet binasına taşınmıştır (T.C. Kültür ve Turizm Bakanlığı, 2021a). Ankara Ali Dayı Çocuk Kütüphanesi ise Ankara 100. Yıl Mahallesi Nene Hatun Caddesinde bulunan bahçe içerisindeki iki katlı bir binadan oluşmaktadır. Emekli vali merhum Hamdullah Şükrü Kenanoğlu tarafından 1985 yılında Türkiye Cumhuriyeti Kültür ve Turizm Bakanlığına bağışlanmıştır (T.C. Kültür ve Turizm Bakanlı̆̆ı, 2021b). Çalışmanın örneklemini oluşturan bir diğer kütüphane ise Altındağ İlçe Halk Kütüphanesidir. Bu kütüphane 2017 tarihinde hizmet vermeye başlamış olup, 
kütüphane bünyesinde farklı yaş gruplarına yönelik bölümler ve engelli bireylere hizmet veren bir bölüm yer almaktadır (Adnan Ötüken Halk Kütüphanesi, 2021).

Cebeci Halk Kütüphanesi, 1972 yılında Kütüphaneler Genel Müdürlüğüne bağlı olarak hizmete açılmıştır. 1978 yılında ise kütüphane bünyesinde çocuk bölümü hizmete girmiştir. (T.C. Kültür ve Turizm Bakanlığı, 2021c). Çalışma kapsamında incelenen bir diğer kütüphane Keçiören Cemil Meriç İlçe Halk Kütüphanesidir. Bu kütüphane, Kütüphaneler ve Yayımlar Genel Müdürlüğüne bağlı olarak 2014'ten bu yana Keçiören Belediyesince yaptırılan Yunus Emre Kültür Merkezi içerisinde hizmet vermeye devam etmektedir. Kütüphane "Çocuk ve Halk Kütüphanelerini İyileştirme Projesi” kapsamında belirlenen ihtiyaç doğrultusunda kurulmuştur (T.C. Kültür ve Turizm Bakanlığı, 2021d).

Mamak İlçe Halk Kütüphanesi, 1994 yılında kurulmuş olup, 2007 yılına kadar Mamak Kültür ve Sanat Evi adı altında hizmet sunmuştur. 2005 yılında yeri değiştirilen kütüphane Mamak Kültür Merkezi içinde hizmetine devam etmektedir (T.C. Kültür ve Turizm Bakanlığ1, 2021e). Son olarak, çalışma kapsamında ele alınan Sincan İlçe Halk Kütüphanesi ise 1999 yılında kurulmuştur. 2018 yılında Yavuz Sultan Selim Kültür Merkezine taşınan kütüphane son olarak hizmet kalitesini ve ulaşılabilirliğini artırabilmek amacıyla günümüzde yeni taşındığı binada hizmetine devam etmektedir (T.C. Kültür ve Turizm Bakanlığı, 2021f).

\section{Veri Toplama Araçları}

Çalışmada veri toplama aracı olarak "Çocuk Kütüphaneleri Fiziksel Durum Kontrol Listesi” (EK-1) kullanılmıştır. Bu kontrol listesi araştırmacılar tarafından çocuk kütüphanelerinin fiziksel durumunu değerlendirme amacı ile oluşturulmuştur.

Alanda, bu çalışma kapsamında oluşturulan "Çocuk Kütüphaneleri Fiziksel Durum Kontrol Listesi”"ne benzer bir liste "Bina Değerlendirme ve Denetim” başlığı ile "Çocuk Kütüphanesi Hizmetleri Kılavuzu” (Yılmaz, 2019) isimli kitapta basılmış olup bu kaynakta bina özellikleri iç mekân ve dış mekân olarak sınıflandırılmıştır. Bu çalışma kapsamında oluşturulan "Çocuk Kütüphaneleri Fiziksel Durum Kontrol Listesi” ise hem kapsamı (bina özellikleri, güvenlik donanımı ve malzeme özellikleri) hem de kontrol listesinin oluşturulması aşamasında uzman görüşünün kullanılması bakımından "Bina Değerlendirme ve Denetim” listesinden farklılaşmaktadır. Ayrıca her iki kontrol listesi de benzer zaman diliminde birbirinden bağımsız olarak literatüre kazandırılmıştır.

Çalışma kapsamında oluşturulan “Çocuk Kütüphaneleri Fiziksel Durum Kontrol Listesi” yapılan gerekli alan yazın taraması sonucu IFLA'nın yayınladığı rehberler ve standartlar göz önünde bulundurularak (Adcock, 2011; IFLA, 2003; IFLA, 2006; IFLA 2007; IFLA, 2009; IFLA, 2015) 73 madde olarak hazırlanmıştır. Bu kontrol listesi bina, güvenlik donanımı ve malzeme özelliklerini değerlendirmek amacıyla üç alt bölümden oluşmaktadır. Kontrol listesi hazırlandıktan sonra geçerlik çalışması için meslek grupları mimar, iç mimar, inşaat mühendisi, okul öncesi öğretmeni ve kütüphane personeli olmak üzere toplam 12 uzmanın görüşüne gönderilmiştir. Kontrol listesindeki maddelerin uygunluk durumları "Gerekli", "Yetersiz" ve "Gereksiz" ifadeleriyle sorularak belirlenmiştir. Kapsam geçerliliği için gelen uzman görüşleri Lawshe (1975, s. 566) tekniği ile değerlendirilmiştir. Buna göre, öncelikle her bir madde için Kapsam Geçerlik Oranları (KGO) bulunmuştur. 
Ankara'daki Halk Kütüphanesi Çocuk Bölümleri ve Çocuk Kütüphanelerinin Bina, Güvenlik Donanımı ve Malzeme Niteliklerinin İncelenmesi

Investigation of Building, Security Equipment and Material Qualifications of Public Library Children's Departments and Children's Libraries in Ankara

Kapsam Geçerlik Oranları, maddelere "Gerekli” yanıtını veren uzman sayısının toplam uzman sayısına bölünmesi sonucunda çıkan değerin 1'den çıkarılmasıyla elde edilir (Yurdugül, 2005, s. 2). 12 uzman görüşünün alındığı bir değerlendirme için her bir maddenin $p=0,005$ anlamlılık düzeyinde KGO'ların minimum değerleri 0,56 olması gerekmektedir (Veneziano ve Hooper, 1997, aktaran Yurdugül 2005, s. 2). Çıkan sonuçlara göre eksi değer alan 13 madde çıkarılmış, 0'dan büyük olan ama 0,56'nın altında kalan 7 maddede düzenleme yapılmış, 60 maddelik kontrol listesi oluşturulmuştur. Daha sonra alt boyutlar (bina, güvenlik donanımı ve malzeme özellikleri) ve toplam liste için ayrı ayrı Kapsam Geçerlik İndeksi (KGI) hesaplanmıştır. KGİ hesaplaması için KGO değerleri anlamlı olan maddelerin ortalamaları alınmış ve KGİ bina özellikleri için 0,795; güvenlik donanımı için 0,87; malzeme için 0,761 ve toplam liste için 0,805 olarak belirlenmiştir (Ayr. bkz. EK-1). Yurdugül'e (2005, s. 2) göre KGO değerlerin referans değerinin üzerinde olması durumunda kontrol listesi istatistiksel olarak anlamlı kabul edilir. Elde edilen KGO değerlerinin referans değerinin üzerinde olduğu için kontrol listesi istatistiksel olarak geçerli kabul edilmiştir. Ayrıca üç Türkçe uzmanından kontrol listesinin dil ve ifade yeterliliğine ilişkin görüş alınmış ve çocuk kütüphanelerinin taşıması gereken fiziksel özellikleriyle ilgili kontrol listesine son şekli verilmiştir.

Kontrol listesinde bulunan 60 maddenin gözlem sonucuna göre varlığını veya yokluğunu belirtmek için "Evet" ve "Hayır" ifadeleri kullanılmıştır. Ancak kontrol listesindeki bazı maddelerde "Evet" cevabını işaretlemek için aşağıdaki koşulların sağlanması beklenmiştir:

- Uygun oda sicaklığının 20 ile 25 santigrat derece arasında (Madde 14),

- Minder sayısının en az 15 adet (Madde 43),

- Masa sayisinin en az 4 adet (Madde 44),

- Sandalye sayısının en az 15 adet (Madde 45),

- Boya çeşidinin en az 3 farklı renk (Madde 46),

- Bilgisayar sayısının en az 2 adet (Madde 49),

- Oyuncak sayısının en az 15 tür/çeşit/adet (Madde 52),

- İlan panosunun en az 1 adet (Madde 57),

- Güvenlik kamerasının en az 3 adet (Madde 59) olması.

\section{Veri Toplama Süreci ve Verilerin Analizi}

Çalışmanın örneklemini oluşturan her bir kütüphane, 2019 yılı 25 Ocak - 5 Şubat tarihleri arasında ziyaret edilmiştir. Veri toplama sürecinin başında kütüphaneleri araştırmanın amacına uygun gözlemleyebilmek için Ankara İl Halk Kütüphanesinden gerekli izin alınmıştır. Alınan izin sonrasında çalışmanın yazarları tarafından belirlenen Ankara Adnan Ötüken İl Halk Kütüphanesi çocuk bölümünde, Ankara Ali Dayı Çocuk Kütüphanesinde, Altındağ İlçe Halk Kütüphanesi, Cebeci Halk Kütüphanesi, Keçiören Cemil Meriç İlçe Halk Kütüphanesi, Mamak İlçe Halk Kütüphanesi ve Sincan İlçe Halk Kütüphanesi çocuk bölümünde herhangi bir etkinlik, atölye çalışması vb. durumların olmadığı süre diliminde, iki araştırmacı tarafından gezilerek yerinde inceleme yapılmıştır. Kütüphanelere gidildiğinde ilgili personel bilgilendirilmiş ve her bir kütüphanede 15 ile 45 dakika arası gözlem yapılmıştır. Araştırmacıların kütüphane gözlemleri sırasında objektifliği sağlayabilmek amacıyla herhangi bir kütüphane personelinin 
eşlik etmesi istenmemiştir. Bu sebeple kontrol listeleri, sadece çalışma araştırmacılarının gözlemlerine dayanarak doldurulmuştur. Ayrıca her bir kütüphane 2 araştırmacı tarafından birbirinden bağımsız olarak değerlendirilmiştir. Puanlayıcılar arası tutarlılık için bir deneme

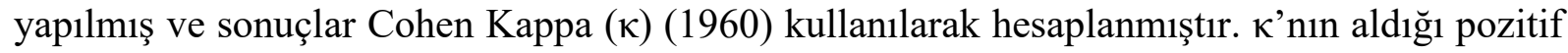
değerler puanlayıcılar arasındaki uyumun şansla beklenen uyumdan daha fazla olduğunun, К'nın aldığı negatif değerler ise puanlayıcılar arasındaki uyumun şansla beklenenden daha az olduğunu göstermektedir (Von Eye ve Mun, 2005, s. 3). Bu bağlamda negatif değerler şansla beklenenin altında bir uyum düzeyi gösterdiği için dikkate alınmamaktadır (Goodwin, 2001, s. 17). $\kappa$ istatistiğinin yorumlanmasında 0 'dan küçük değerlerler "Zayıf”, 0,00 - 0,20 arası değerler “Önemsiz”, 0,21 - 0,40 arası değerler "Düşük", 0,41 - 0,60 arası değerler “Orta”, 0,61 - 0,80 arası değerler "Önemli" ve 0,81 - 1,00 arası değerler "Çok Yüksek" olarak ifade edilmiştir (Landis ve Koch, 1977, s. 165). Çalışma kapsamında gerçekleştirilen gözlemlerin güvenirlik değerleri Tablo 1'de sunulmaktadır.

\section{Tablo 1}

Analitik puanlama anahtarı ile yapılan puanlamaların Kappa istatistiği ile hesaplanan güvenirlik değerleri

\begin{tabular}{llll}
\hline Puanlayıcı Sayısı & Kütüphaneler & Kappa Değeri $(\kappa)$ & $\mathrm{p}$ \\
\hline 2 & Ankara Adnan Ötüken İl Halk Kütüphanesi & 1,000 &, $000^{*}$ \\
2 & Ankara Ali Dayı Çocuk Kütüphanesi & 1,000 &, $000^{*}$ \\
2 & Altındağ İlçe Halk Kütüphanesi & 1,000 &, $000^{*}$ \\
2 & Cebeci İlçe Halk Kütüphanesi & 0,918 &, $000^{*}$ \\
2 & Keçiören Cemil Meriç İlçe Halk Kütüphanesi & 1,000 &, $000^{*}$ \\
2 & Mamak İlçe Halk Kütüphanesi & 0,899 &, $000^{*}$ \\
2 & Sincan İlçe Halk Kütüphanesi & 0,893 &, $000^{*}$ \\
\hline
\end{tabular}

$* \mathrm{p}<0,05$

Tablo 1'e göre yapılan analizler sonucunda araştırmacılar arasındaki tutarlılık katsayısının 0,893 ile 1,00 arasında değiştiği görülmektedir. Bu sonuçlar araştırmacılar arasında yüksek bir uyum olduğu, bu uyumun da istatistiksel olarak anlamlı $(\mathrm{p}<0,05)$ olduğunu işaret etmektedir. Çalışma sonucunda "Çocuk Kütüphanelerinin Fiziksel Durum Kontrol Listesi”nden elde edilen veriler için her bir "Evet" cevabı 1, "Hayır" cevabı 0 olarak kodlanmıştır. Veriler Microsoft Excel programına aktarılmış ve tanımlayıcı istatistiklerden frekans ve yüzde analizi kullanılarak analiz edilmiştir. Sonuçlar, bulgular kısmında tablolar ile gösterilmiştir.

\section{Bulgular}

Ankara ilinde bulunan bir il halk kütüphanesi, bir bağımsız çocuk kütüphanesi, beş ilçe halk kütüphanesinin çocuk bölümlerinin bina, güvenlik donanımı ve malzeme niteliğini ortaya koymak amacıyla gerçekleştirilen çalışmanın bu bölümünde, yapılan analizler sonucunda ortaya çıkan bulgular paylaşılmıştır.

Kütüphanelerin bina özelliklerine dair değerler Tablo 2'de sunulmuştur. 
Ankara’daki Halk Kütüphanesi Çocuk Bölümleri ve Çocuk Kütüphanelerinin Bina, Güvenlik Donanımı ve Malzeme Niteliklerinin İncelenmesi

Investigation of Building, Security Equipment and Material Qualifications of Public Library Children's Departments and Children's Libraries in Ankara

\section{Tablo 2}

Kütüphanelerin bina özelliklerine göre durumları

\begin{tabular}{|c|c|c|c|c|c|c|c|c|}
\hline Bina Özellikleri & $\begin{array}{l}\text { Ankara } \\
\text { Adnan } \\
\text { Ötüken } \\
\text { İl Halk } \\
\text { K. }\end{array}$ & $\begin{array}{l}\text { Ankara } \\
\text { Ali } \\
\text { Dayı } \\
\text { Çocuk } \\
\text { K. }\end{array}$ & $\begin{array}{l}\text { Altındağ } \\
\text { İlçe } \\
\text { Halk K. }\end{array}$ & $\begin{array}{l}\text { Cebeci } \\
\text { İlçe } \\
\text { Halk K. }\end{array}$ & $\begin{array}{l}\text { Keçiören } \\
\text { Cemil } \\
\text { Meriç } \\
\text { İlçe } \\
\text { Halk K. }\end{array}$ & $\begin{array}{l}\text { Mamak } \\
\text { İlçe } \\
\text { Halk } \\
\text { K. }\end{array}$ & $\begin{array}{l}\text { Sincan } \\
\text { İlçe } \\
\text { Halk } \\
\text { K. }\end{array}$ & Toplam \\
\hline $\begin{array}{l}\text { Ulaşım ağlarına yakın } \\
\text { yerdedir. }\end{array}$ & 1 & 1 & 1 & 1 & 1 & 1 & 1 & 7 \\
\hline $\begin{array}{l}\text { Yeterli ve doğru } 1 s ̧ ı k \\
\text { almaktadır. }\end{array}$ & 1 & 1 & 1 & 1 & 1 & 1 & 1 & 7 \\
\hline $\begin{array}{l}\text { Uygun oda sicaklığı } \\
\text { sağlanmıştır. }\end{array}$ & 1 & 1 & 1 & 1 & 1 & 1 & 1 & 7 \\
\hline $\begin{array}{l}\text { Acil durumlar için } \\
\text { gerekli kurumlara } \\
\text { yakındır. }\end{array}$ & 1 & 1 & 1 & 1 & 1 & 1 & 1 & 7 \\
\hline $\begin{array}{l}\text { Kütüphanede } \\
\text { kullanılmayan } \\
\text { malzemeler için depo } \\
\text { vardır. }\end{array}$ & 1 & 1 & 1 & 1 & 1 & 1 & 1 & 7 \\
\hline $\begin{array}{l}\text { Binada nem, küf, } \\
\text { böcek vb. yoktur. }\end{array}$ & 1 & 1 & 1 & 1 & 1 & 1 & 1 & 7 \\
\hline $\begin{array}{l}\text { Kütüphane binasında } \\
\text { özel gereksinimli } \\
\text { bireyler için } \\
\text { rampa/asansör vardır. }\end{array}$ & 1 & 1 & 1 & 0 & 1 & 0 & 1 & 5 \\
\hline $\begin{array}{l}\text { Bebek arabasının } \\
\text { kullanılabileceği } \\
\text { rampa ya da asansör } \\
\text { vardır. }\end{array}$ & 1 & 1 & 1 & 0 & 1 & 0 & 1 & 5 \\
\hline $\begin{array}{l}\text { Binada birbirinden } \\
\text { bağımsız alanlar arası } \\
\text { ulaşım kolaydır. }\end{array}$ & 0 & 1 & 1 & 0 & 1 & 1 & 1 & 5 \\
\hline $\begin{array}{l}\text { Mobilyalar ve } \\
\text { dekorasyon } \\
\text { çocukların yaş } \\
\text { grubuna uygundur. }\end{array}$ & 0 & 1 & 1 & 0 & 1 & 1 & 0 & 4 \\
\hline $\begin{array}{l}\text { Yerler kaygan } \\
\text { değildir. }\end{array}$ & 1 & 1 & 0 & 0 & 0 & 1 & 0 & 3 \\
\hline $\begin{array}{l}\text { Sessiz alanlar kadar } \\
\text { sesli alanlar vardır. }\end{array}$ & 1 & 1 & 0 & 0 & 1 & 0 & 0 & 3 \\
\hline $\begin{array}{l}\text { Belirli alanlarda kolay } \\
\text { temizlenebilir zemin } \\
\text { vardır. }\end{array}$ & 0 & 1 & 0 & 0 & 1 & 1 & 0 & 3 \\
\hline $\begin{array}{l}\text { Sesli ve sessiz alanlar } \\
\text { birbirini } \\
\text { etkilemeyecek şekilde } \\
\text { konumlandırılmıştır. }\end{array}$ & 1 & 1 & 0 & 0 & 1 & 0 & 0 & 3 \\
\hline $\begin{array}{l}\text { Görevli araç otoparkı } \\
\text { vardır. }\end{array}$ & 1 & 0 & 0 & 0 & 1 & 1 & 0 & 3 \\
\hline $\begin{array}{l}\text { Yerler yumuşak } \\
\text { zemindir. }\end{array}$ & 0 & 1 & 0 & 0 & 0 & 1 & 0 & 2 \\
\hline $\begin{array}{l}\text { Renklerin tanımlayıcı } \\
\text { ve yönlendirici } \\
\text { özellikleri göz önünde }\end{array}$ & 0 & 1 & 0 & 0 & 0 & 1 & 0 & 2 \\
\hline
\end{tabular}




\begin{tabular}{|c|c|c|c|c|c|c|c|c|}
\hline $\begin{array}{l}\text { bulundurularak } \\
\text { dekore edilmiştir. }\end{array}$ & & & & & & & & \\
\hline $\begin{array}{l}\text { Ebeveynlerin vakit } \\
\text { geçirebileceği açık } \\
\text { veya kapalı alanlar } \\
\text { vardır. }\end{array}$ & 0 & 0 & 1 & 0 & 0 & 0 & 1 & 2 \\
\hline $\begin{array}{l}\text { Nitelikli vakit } \\
\text { geçirilebilecek açık } \\
\text { alanlar vardır. }\end{array}$ & 0 & 1 & 1 & 0 & 0 & 0 & 0 & 2 \\
\hline $\begin{array}{l}\text { Lavabolar çocukların } \\
\text { boylarına uygundur. }\end{array}$ & 0 & 1 & 0 & 0 & 0 & 0 & 0 & 1 \\
\hline $\begin{array}{l}\text { Lavabo zeminleri } \\
\text { çocukların } \\
\text { kaymayacağı } \\
\text { şekildedir. }\end{array}$ & 0 & 1 & 0 & 0 & 0 & 0 & 0 & 1 \\
\hline $\begin{array}{l}\text { Kullanıcılar ve } \\
\text { misafirler için araç } \\
\text { otoparkı vardır. }\end{array}$ & 0 & 0 & 0 & 0 & 1 & 0 & 0 & 1 \\
\hline $\begin{array}{l}\text { Kullanıcıların } \\
\text { ihtiyaçlarını } \\
\text { karşılayabilecek bir } \\
\text { kafeterya vardır. }\end{array}$ & 0 & 0 & 0 & 0 & 1 & 0 & 0 & 1 \\
\hline $\begin{array}{l}\text { Bebek bakım odası } \\
\text { vardır. }\end{array}$ & 0 & 0 & 0 & 0 & 0 & 0 & 0 & 0 \\
\hline Toplam & 12 & 19 & 12 & 6 & 16 & 13 & 10 & 88 \\
\hline
\end{tabular}

Tablo 2 incelendiğinde, bina niteliği bakımından araştırma kapsamında gözlemlenen kütüphanelerin tamamının ulaşım ağlarına yakın yerde olduğu, yeterli ve doğru 1şık almakta olduğu, uygun oda sıcaklığına sahip olduğu, acil durumlar için gerekli kurumlara yakın olduğu, binalarda nem, küf, böcek vb. bulunmadığı ve kütüphanede kullanılmayan malzemeler için depo bulunduğu görülmektedir. Diğer yandan kütüphane binalarının hiçbirinde bebek bakım odası bulunmamaktadır. Ayrıca kullanıcıların ihtiyaçlarını karşılayabilecek bir kafeterya, kullanıcılar ve misafirler için araç otoparkı, çocukların boylarına uygun, çocukların kaymayacağı şekilde zemine sahip olan lavabolar incelenen kütüphanelerden yalnızca birinde bulunmaktadir.

Tablo 2'ye göre Ankara Adnan Ötüken İl Halk Kütüphanesi incelendiğinde bina özelliklerine ilişkin maddelerin yarısından olumlu puan aldığg görülmektedir. Ankara Ali Dayı Çocuk Kütüphanesi ise diğer kütüphaneler ile karşılaştırıldığında en fazla olumlu puan alan kütüphanedir. Ayrıca Ankara Ali Dayı Çocuk Kütüphanesinde lavabolar çocukların boylarına uygun ve lavabo zeminleri çocukların kaymayacağı şekildeyken geriye kalan hiçbir kütüphanede bu özellikler bulunmamaktadır.

Altındağ İlçe Halk Kütüphanesinin ise bina özelliklerine ilişkin bulguları incelendiğinde bina özellikleri ile ilgili maddelerin yarısından olumlu puan aldığı görülmektedir. Cebeci İlçe Halk Kütüphane binası özellikleri bakımından en az olumlu puan alan kütüphanedir. Kütüphane binalarında olması gereken 24 özelliğin yalnızca altısından olumlu puan alan kütüphane, incelenen kütüphaneler arasında en düşük puana sahip olan kütüphanedir.

Keçiören Cemil Meriç İlçe Halk Kütüphanesi incelendiğinde bina özelliklerine ilişkin maddelerin yarısından fazlasının olumlu olarak işaretlendiği görülmektedir. Ayrıca Keçiören 
Ankara’daki Halk Kütüphanesi Çocuk Bölümleri ve Çocuk Kütüphanelerinin Bina, Güvenlik Donanımı ve Malzeme Niteliklerinin İncelenmesi

Investigation of Building, Security Equipment and Material Qualifications of Public Library Children's Departments and Children's Libraries in Ankara

Cemil Meriç İlçe Halk Kütüphanesinde diğer kütüphanelerde olmayan araç otoparkı ve kullanıcıların ihtiyaçlarını karşılayabilecek kafeterya bulunmaktadır. Mamak İlçe Halk Kütüphanesi ve Sincan İlçe Halk Kütüphanesi, bina özellikleri bakımından incelendiğinde kontrol listesindeki maddelerin yarısına yakınından olumlu puan aldıkları görülmektedir (Ayr. bkz. EK-1 Çocuk Kütüphaneleri Fiziksel Durum Kontrol Listesi).

Kütüphanelerin güvenlik donanımına ilişkin bulgular Tablo 3 'te sunulmuştur.

Tablo 3

Kütüphanelerin güvenlik donanımına göre durumları

\begin{tabular}{|c|c|c|c|c|c|c|c|c|}
\hline Güvenlik Donanımı & $\begin{array}{l}\text { Ankara } \\
\text { Adnan } \\
\text { Ötüken İl } \\
\text { Halk K. }\end{array}$ & $\begin{array}{l}\text { Ankara } \\
\text { Ali } \\
\text { Dayı } \\
\text { Çocuk } \\
\text { K. } \\
\end{array}$ & $\begin{array}{l}\text { Altındağ } \\
\text { İlçe Halk } \\
\text { K. }\end{array}$ & $\begin{array}{l}\text { Cebeci } \\
\text { İlçe } \\
\text { Halk } \\
\text { K. }\end{array}$ & $\begin{array}{l}\text { Keçiören } \\
\text { Cemil } \\
\text { Meriç İlçe } \\
\text { Halk K. }\end{array}$ & $\begin{array}{l}\text { Mamak } \\
\text { İlçe Halk } \\
\text { K. }\end{array}$ & $\begin{array}{l}\text { Sincan } \\
\text { İlçe } \\
\text { Halk } \\
\text { K. }\end{array}$ & Toplam \\
\hline Yangın tüpü vardır. & 1 & 1 & 1 & 1 & 1 & 1 & 1 & 7 \\
\hline İlk yardım seti vardır. & 1 & 1 & 1 & 1 & 1 & 1 & 0 & 6 \\
\hline $\begin{array}{l}\text { Merdiven boşlukları } \\
\text { çocukların güvenliğini } \\
\text { tehdit etmeyecek } \\
\text { şekildedir. }\end{array}$ & 1 & 1 & 1 & 1 & 1 & 0 & 0 & 5 \\
\hline $\begin{array}{l}\text { Merdiven tırabzanları } \\
\text { çocuklar için uygundur. }\end{array}$ & 1 & 1 & 1 & 1 & 1 & 0 & 0 & 5 \\
\hline $\begin{array}{l}\text { Olası kazaları önlemek } \\
\text { için kapı ve cam } \\
\text { pervazlarına yönelik } \\
\text { gerekli tedbirler } \\
\text { alınmıştır. }\end{array}$ & 0 & 1 & 1 & 0 & 1 & 1 & 0 & 4 \\
\hline $\begin{array}{l}\text { Duman, yangın ve su } \\
\text { algılama sistemi vardır. }\end{array}$ & 1 & 1 & 0 & 0 & 1 & 0 & 1 & 4 \\
\hline $\begin{array}{l}\text { Malzeme kenarları } \\
\text { keskin değildir. }\end{array}$ & 0 & 1 & 0 & 0 & 0 & 1 & 1 & 3 \\
\hline $\begin{array}{l}\text { Olağanüstü herhangi bir } \\
\text { durum için yönlendirici } \\
\text { işaret ve gerekli } \\
\text { malzemeler } \\
\text { yerleştirilmiştir. }\end{array}$ & 0 & 1 & 1 & 0 & 1 & 0 & 0 & 3 \\
\hline $\begin{array}{l}\text { Acil toplanma merkezi } \\
\text { vardır. }\end{array}$ & 1 & 0 & 0 & 0 & 0 & 0 & 1 & 2 \\
\hline $\begin{array}{l}\text { Isıtıcılar çocukların } \\
\text { ulaşamayacağı alandadır. }\end{array}$ & 0 & 0 & 1 & 0 & 1 & 0 & 0 & 2 \\
\hline $\begin{array}{l}\text { Merdiven basamakları } \\
\text { kaygan değildir. }\end{array}$ & 0 & 1 & 0 & 0 & 0 & 0 & 0 & 1 \\
\hline $\begin{array}{l}\text { Mobilyalar çocuklar için } \\
\text { tehlike arz etmemektedir. }\end{array}$ & 0 & 1 & 0 & 0 & 0 & 0 & 0 & 1 \\
\hline $\begin{array}{l}\text { Acil durum bilgi } \\
\text { kitapçı̆ı mevcut ve } \\
\text { ulaşılabilir durumdadır. }\end{array}$ & 0 & 1 & 0 & 0 & 0 & 0 & 0 & 1 \\
\hline $\begin{array}{l}\text { Binada yıldırımsavar } \\
\text { vardır. }\end{array}$ & 1 & 0 & 0 & 0 & 0 & 0 & 0 & 1 \\
\hline $\begin{array}{l}\text { Elektrik prizleri } \\
\text { kapalıdır. }\end{array}$ & 0 & 0 & 0 & 0 & 0 & 0 & 0 & 0 \\
\hline $\begin{array}{l}\text { Bakım odasında gerekli } \\
\text { hijyenik malzemeler } \\
\text { vardır. }\end{array}$ & 0 & 0 & 0 & 0 & 0 & 0 & 0 & 0 \\
\hline $\begin{array}{l}\text { Otomatik yangın } \\
\text { söndürme sistemi vardır. }\end{array}$ & 0 & 0 & 0 & 0 & 0 & 0 & 0 & 0 \\
\hline Toplam & 7 & 11 & 7 & 4 & 8 & 4 & 4 & 45 \\
\hline
\end{tabular}


Tablo 3 değerleri incelendiğinde güvenlik donanımı bakımından incelenen kütüphanelerin tamamında yangın tüpü olmasına karşın hiçbirinde otomatik yangın söndürme sistemi bulunmamaktadır. Yine kütüphanelerin hiçbirinde elektrik prizleri kapalı değildir ve bakım odasında gerekli hijyenik malzemeler bulundurulmamaktadır. Ayrıca incelenen yedi kütüphaneden yalnızca birinin yıldırımsavar, acil durum bilgi kitapçığı, kaygan olmayan merdiven basamakları ve çocuklar için tehlike arz etmeyen mobilyalara sahip olduğu görülmektedir.

Ankara Adnan Ötüken İl Halk Kütüphanesi, 16 güvenlik donanımı özelliğinin yarısından olumlu puan almıştır. Ayrıca bu kütüphane binasında diğer kütüphanelerden farklı olarak yıldırımsavar bulunmaktadır. Acil toplanma merkezi ise yalnızca Ankara Adnan Ötüken İl Halk Kütüphanesi ve Sincan İlçe Halk Kütüphanesinde bulunmaktadır.

Ankara Ali Dayı Çocuk Kütüphanesinin diğer kütüphanelere kıyasla güvenlik donanımı bakımından en fazla olumlu puan alan kütüphane olduğu görülmektedir. Bu kütüphanede merdiven basamakları kaygan değildir, mobilyalar çocuklar için tehlike arz etmemektedir ve acil durum bilgi kitapçığ mevcut ve ulaşılabilir durumdadır. Geriye kalan hiçbir kütüphanede bu özelliklere rastlanılmamıştır.

Altındağ İlçe Halk Kütüphanesi, güvenlik donanımına göre değerlendirildiğinde incelenen 16 özelliğin yarısına yakınından olumlu puan aldığı görülmektedir. Diğer yandan Keçiören Cemil Meriç İlçe Halk Kütüphanesi, güvenlik donanımına göre değerlendirildiğinde incelenen 16 özelliğin yarısından fazlasından olumlu puan aldığı görülmektedir. Ayrıca incelenen kütüphaneler arasından sadece Altındağ İlçe Halk Kütüphanesi ve Keçiören Cemil Meriç İlçe Halk Kütüphanesinde 1sıtıcılar çocukların ulaşamayacağı yerdedir.

Cebeci İlçe Halk Kütüphanesi, Mamak İlçe Halk Kütüphanesi ve Sincan İlçe Halk Kütüphanesi ise güvenlik donanımına göre diğer kütüphaneler ile karşılaştırıldığında en az olumlu puan alan kütüphaneler arasındadır. Ayrıca her kütüphanede gözlemlenen ilk yardım setinin Sincan İlçe Halk Kütüphanesinde gözlemlenmediği çalışmanın bulguları arasındadır (Ayr. bkz. EK-1 Çocuk Kütüphaneleri Fiziksel Durum Kontrol Listesi).

Kütüphanelerin malzeme özelliklerine ilişkin bulgular Tablo 4'te sunulmuştur.

\section{Tablo 4}

Kütüphanelerin malzeme özelliklerine göre durumları

\begin{tabular}{|c|c|c|c|c|c|c|c|c|}
\hline Malzeme Özelliği & $\begin{array}{l}\text { Ankara } \\
\text { Adnan } \\
\text { Ötüken } \\
\text { İl Halk } \\
\text { K. }\end{array}$ & $\begin{array}{l}\text { Ankara } \\
\text { Ali } \\
\text { Dayı } \\
\text { Çocuk } \\
\text { K. }\end{array}$ & $\begin{array}{l}\text { Altındağ } \\
\text { İlçe } \\
\text { Halk K. }\end{array}$ & $\begin{array}{l}\text { Cebeci } \\
\text { İlçe } \\
\text { Halk } \\
\text { K. }\end{array}$ & $\begin{array}{l}\text { Keçiören } \\
\text { Cemil } \\
\text { Meriç } \\
\text { İlçe } \\
\text { Halk K. }\end{array}$ & $\begin{array}{l}\text { Mamak } \\
\text { İlçe } \\
\text { Halk } \\
\text { K. }\end{array}$ & $\begin{array}{l}\text { Sincan } \\
\text { İlçe } \\
\text { Halk } \\
\text { K. }\end{array}$ & Toplam \\
\hline $\begin{array}{l}\text { Çocuklar için ödünç } \\
\text { alma masası vardır. }\end{array}$ & 1 & 1 & 1 & 1 & 1 & 1 & 1 & 7 \\
\hline $\begin{array}{l}\text { Yutulabilecek ve } \\
\text { tehlikeli olabilecek } \\
\text { küçük malzemeler } \\
\text { yoktur. }\end{array}$ & 1 & 1 & 1 & 1 & 1 & 1 & 1 & 7 \\
\hline $\begin{array}{l}\text { Personel masası } \\
\text { çocukların görebileceği } \\
\text { bir noktadadır. }\end{array}$ & 1 & 1 & 1 & 1 & 1 & 1 & 1 & 7 \\
\hline $\begin{array}{l}\text { Fotokopi ve tarayıcı } \\
\text { makinesi vardır. }\end{array}$ & 1 & 1 & 1 & 1 & 1 & 1 & 1 & 7 \\
\hline
\end{tabular}


Ankara’daki Halk Kütüphanesi Çocuk Bölümleri ve Çocuk Kütüphanelerinin Bina, Güvenlik Donanımı ve Malzeme Niteliklerinin İncelenmesi

Investigation of Building, Security Equipment and Material Qualifications of Public Library Children's Departments and Children's Libraries in Ankara

\begin{tabular}{|c|c|c|c|c|c|c|c|c|}
\hline $\begin{array}{l}\text { Çocukların fiziksel } \\
\text { gelişim düzeylerine } \\
\text { uygun masalar vardır. }\end{array}$ & 1 & 1 & 1 & 0 & 1 & 1 & 1 & 6 \\
\hline $\begin{array}{l}\text { Çocukların güvenli bir } \\
\text { şekilde kullanabileceği } \\
\text { sandalyeler vardır. }\end{array}$ & 1 & 1 & 1 & 0 & 1 & 1 & 1 & 6 \\
\hline İlan panosu vardır. & 1 & 1 & 1 & 1 & 1 & 1 & 0 & 6 \\
\hline $\begin{array}{l}\text { Uygun noktalarda } \\
\text { güvenlik kameraları } \\
\text { vardır. }\end{array}$ & 1 & 0 & 1 & 1 & 1 & 1 & 1 & 6 \\
\hline Hoparlör vardır. & 0 & 1 & 1 & 1 & 1 & 1 & 0 & 5 \\
\hline $\begin{array}{l}\text { Raflar çocukların göz } \\
\text { hizasındadır. }\end{array}$ & 1 & 1 & 0 & 0 & 1 & 1 & 0 & 4 \\
\hline Projeksiyon aleti vardır. & 0 & 1 & 0 & 1 & 1 & 0 & 0 & 3 \\
\hline $\begin{array}{l}\text { Çocukların yaş } \\
\text { gruplarına uygun olarak } \\
\text { kullanabileceği çeşitli ve } \\
\text { yeterli sayıda boyalar } \\
\text { vardır. }\end{array}$ & 0 & 1 & 0 & 0 & 1 & 0 & 0 & 2 \\
\hline $\begin{array}{l}\text { Çocukların kullanımı } \\
\text { için bilgisayarlar vardır. }\end{array}$ & 0 & 1 & 0 & 0 & 1 & 0 & 0 & 2 \\
\hline $\begin{array}{l}\text { Çok dilli çocuklara } \\
\text { uygun görsel-işitsel } \\
\text { materyal vardır. }\end{array}$ & 0 & 1 & 0 & 0 & 1 & 0 & 0 & 2 \\
\hline $\begin{array}{l}\text { Çocukların gelişim } \\
\text { düzeylerine uygun } \\
\text { oyuncaklar vardır. }\end{array}$ & 0 & 1 & 0 & 0 & 1 & 0 & 0 & 2 \\
\hline $\begin{array}{l}\text { Kitapların yerini ya da } \\
\text { özel alanları gösteren } \\
\text { semboller vardır. }\end{array}$ & 1 & 1 & 0 & 0 & 0 & 0 & 0 & 2 \\
\hline $\begin{array}{l}\text { Çocuk sayısı ile orantılı } \\
\text { sayıda kullanılabilecek } \\
\text { hijyenik minderler } \\
\text { vardır. }\end{array}$ & 0 & 1 & 0 & 0 & 0 & 0 & 0 & 1 \\
\hline $\begin{array}{l}\text { Toplumdaki kültürel } \\
\text { çeşitliliği sergileyici } \\
\text { materyal (kitap, } \\
\text { oyuncak, CD vb.) vardır. }\end{array}$ & 0 & 0 & 0 & 0 & 1 & 0 & 0 & 1 \\
\hline $\begin{array}{l}\text { Ebeveyn odasında } \\
\text { ebeveynlere yönelik } \\
\text { kitaplar vardır. }\end{array}$ & 0 & 0 & 0 & 0 & 0 & 0 & 1 & 1 \\
\hline Toplam & 10 & 16 & 9 & 8 & 16 & 10 & 8 & 77 \\
\hline
\end{tabular}

Tablo 4'te verilen bulgulara bakıldığında, incelenen kütüphanelerinin tamamının çocuklar için ödünç alma masasına sahip olduğu, personel masasının çocukların görebileceği bir noktada olduğu, fotokopi ve tarayıcı makinelerinin bulunduğu görülmektedir. Ayrıca kütüphanelerin hiçbirinde yutulabilecek ve tehlikeli olabilecek küçük malzemeler kullanıcıların erişebileceği bir yerde bulundurulmamaktadır. Sadece bir kütüphanede çocuk sayısı ile orantılı sayıda kullanılabilecek hijyenik minderler, toplumdaki kültürel çeşitliliği sergileyici materyaller (kitap, oyuncak, CD vb.) ve ebeveyn odasında ebeveynlere yönelik kitaplar görülmüştür. 
Ankara Adnan Ötüken İl Halk Kütüphanesinin incelenen özelliklerin yarısından fazlasından olumlu puan aldığı görülmektedir. Ayrıca yalnızca Ankara Adnan Ötüken İl Halk Kütüphanesi ve Ankara Ali Dayı Çocuk Kütüphanesinde kitapların yerini ya da özel alanlarını gösteren sembollerin bulunduğu çalışmanın bulguları arasındadır.

Ankara Ali Dayı Çocuk Kütüphanesi diğer kütüphaneler ile karşılaştırıldığında en fazla olumlu puan alan kütüphaneler arasında bulunmaktadır. Kütüphanede diğer kütüphanelerden farklı olarak çocuk sayısı ile orantılı sayıda kullanılabilecek hijyenik minderler bulunmaktadır. Ayrıca yalnızca Ankara Ali Dayı Çocuk Kütüphanesi ve Keçiören Cemil Meriç İlçe Halk Kütüphanesinde çocukların yaş gruplarına uygun olarak kullanabileceği çeşitli ve yeterli sayıda boyalar, çocukların kullanımı için bilgisayarlar ve çocukların gelişim düzeylerine uygun oyuncaklar bulunmaktadır. Geriye kalan diğer kütüphanelerde bu özelliklere rastlanılmamıştır.

Altındağ İlçe Halk Kütüphanesi ile Cebeci İlçe Halk Kütüphanesi incelenen özelliklerin yarısından olumlu puan almıştır. Bunun yanında diğer tüm kütüphanelerde gözlemlenen çocukların fiziksel gelişim düzeylerine uygun masalar ve çocukların güvenli bir şekilde kullanabileceği sandalyeler yalnızca Cebeci İlçe Halk Kütüphanesinde bulunmamaktadır.

Keçiören Cemil Meriç İlçe Halk Kütüphanesi diğer kütüphaneler ile karşılaştırıldığında en fazla olumlu puan alan iki kütüphaneden biridir. Ayrıca Keçiören Cemil Meriç İlçe Halk Kütüphanesinde diğer kütüphanelerde olmayan, farklı dil, din ve 1rkları içeren, "toplumdaki kültürel çeşitliliği sergileyici materyaller (kitap, oyuncak, CD vb.)" maddesinden de olumlu puan aldığı çalışmanın bulguları arasındadır.

Mamak İlçe Halk Kütüphanesi malzeme niteliğine ilişkin değerlendirilen özelliklerin yarısından fazlasından olumlu puan almıştır. İncelenen Sincan İlçe Halk Kütüphanesi ise malzeme özelliklerine göre değerlendirildiğinde incelenen özelliklerin yarısına yakınından olumlu puan aldığı görülmektedir. Ayrıca diğer kütüphanelerin tamamında var olan ilan panosunun Sincan İlçe Halk Kütüphanesinde bulunmadığ 1 görülmektedir (Ayr. bkz. EK-1 Çocuk Kütüphaneleri Fiziksel Durum Kontrol Listesi).

Kütüphanelerin bina, güvenlik donanımı ve malzeme özelliklerine ilişkin genel bulgular Tablo 5'te sunulmuştur.

\section{Tablo 5}

Kütüphanelerin bina, güvenlik donanımı ve malzeme özelliklerine göre durumu

Kütüphaneler

Ankara Adnan Ötüken İl Halk Kütüphanesi Ankara Ali Dayı Çocuk Kütüphanesi Altındağ İlçe Halk Kütüphanesi Cebeci İlçe Halk Kütüphanesi

Keçiören Cemil Meriç İlçe Halk Kütüphanesi

Mamak İlçe Halk Kütüphanesi

Sincan İlçe Halk Kütüphanesi

\begin{tabular}{cccc} 
& Evet & \multicolumn{2}{c}{ Hayır } \\
\hline $\mathrm{f}$ & $\%$ & $\mathrm{f}$ & $\%$ \\
\hline 29 & 48 & 31 & 52 \\
46 & 77 & 14 & 23 \\
28 & 47 & 32 & 53 \\
18 & 30 & 42 & 70 \\
40 & 67 & 20 & 33 \\
27 & 45 & 33 & 55 \\
22 & 37 & 38 & 63 \\
\hline
\end{tabular}

Tablo 5'te çalışma kapsamında incelenen kütüphanelerin bina, güvenlik donanımı ve malzeme özelliklerine göre durumları gösterilmektedir. Bina, güvenlik donanımı ve malzeme özellikleri bakımından ortalamanın üstünde puan alan kütüphaneler Ankara Ali Dayı Çocuk 
Ankara'daki Halk Kütüphanesi Çocuk Bölümleri ve Çocuk Kütüphanelerinin Bina, Güvenlik Donanımı ve Malzeme Niteliklerinin İncelenmesi

Investigation of Building, Security Equipment and Material Qualifications of Public Library Children's

Kütüphanesi ve Keçiören Cemil Meriç İlçe Halk Kütüphanesidir. Geriye kalan beş kütüphaneden üçü (Adnan Ötüken İl Halk Kütüphanesi Çocuk Bölümü, Mamak İlçe Halk Kütüphanesi Çocuk Bölümü ve Altındağ İlçe Halk Kütüphanesi Çocuk Bölümü) incelenen özellikler bakımından ortalama puana sahipken, Cebeci Halk Kütüphanesi Çocuk Bölümünün ve Sincan İlçe Halk Kütüphanesi Çocuk Bölümünün bina, güvenlik donanımı ve malzeme özellikleri bakımından ortalamanın altında puan aldığı görülmektedir.

\section{Tartışma}

Çalışmanın bulguları incelendiğinde bina nitelikleri bakımından değerlendirilen kütüphanelerin tamamının ulaşım ağlarına yakın yerde olduğu, yeterli ve doğru 1şık almakta olduğu, uygun oda sıcaklığına sahip olduğu, acil durumlar için gerekli kurumlara yakın olduğu, binalarda nem, küf, böcek vb. bulunmadığı ve kütüphanede kullanılmayan malzemeler için depo bulunduğu görülmektedir. $\mathrm{Bu}$ özellikler iyi kütüphane binalarında bulunması gereken temel özelliklerdendir. Örneğin Valente Library ve Sunset Park Library kütüphane binaları merkezi ve kolay ulaşılabilir konumu, yeterli ve doğru 1şı alan, adeta insanları içeri davet eden şeffaf yapısı, çocukların güvenliğini gözeten, aktif mekânlarının olması gibi özelliklerinin varlığından dolayı iyi kütüphane binası olarak ifade edilmektedir ve 2021 yılında American Library Association (ALA) tarafından kütüphane yapılarının ve tasarımlarının her yönden incelenmesi sonucu verilen tek ödül olan “AIA / ALA En İyi Kütüphane Binası Ödülünü” almışlardır (AIA, 2021). Diğer yandan incelenen hiçbir kütüphane binasında bebek bakım odası gözlemlenmemiştir. Ayrıca bir kütüphane binası hariç diğer hiçbir kütüphanede araç otoparkı ve kullanıcıların ihtiyaçlarını karşılayacak kafeterya gözlemlenmemiştir. $\mathrm{Bu}$ noktada Ankara'daki kütüphanelerin bebek bakım odası, araç otoparkı ve kafeterya yönünde eksikliği olduğu ortaya çıkmaktadır. İstanbul' daki halk ve çocuk kütüphanelerinde yapılan bir çalışmada bu çalışmanın bulguları ile tutarlı olarak; kullanıcının ihtiyaç ve beklentisine göre düzenlenmiş, tasarlanmış olması gereken halk kütüphanelerinin bu gereklilikten son derece uzak olduğu tespit edilmiştir (Kakırman Yıldız, Yalçınkaya ve Saydam, 2018, s. 1833). Oysa alan yazında iyi tasarlanmış kütüphane binalarının bebek bakım odası (IFLA, 2007), araç otoparkı ve kafeterya (KYGM, 2017a) gibi alanları kapsayacak ve kullanıcıların ihtiyaçlarını karşılayacak şekilde çok işlevli bir yapıya sahip olması gerekliliğine değinilmiştir. Ayrıca kütüphane binaları bebekler, bakıcılar, ebeveynler için erişilebilir, güvenli ve çekici mekânlar olmalıdır (Yılmaz, 2019, s. 21). Fakat kütüphanede araç otopark1, bebek bakım odası ve/veya kafeteryanın olmaması hem bebekler hem de bakıcı ve ebeveynler için çocuk kütüphanelerinin herkes tarafından erişilebilir ve çekici olma misyonunu desteklememektedir.

Çalışmanın bir diğer bulgusu, güvenlik donanımı bakımından incelenen çocuk kütüphanelerinin tamamında yangın tüpü bulunmasına rağmen kütüphanelerin hiçbirinde otomatik yangın söndürme sistemlerinin bulunmadığ 1 , elektrik prizlerinin kapalı olmadığı, bakım odasında ihtiyaç olabilecek hijyenik malzemeler bulunmadığını göstermesidir. Oysaki kütüphane tasarlarken; otomatik yangın söndürme sisteminin getireceği faydalar göz önünde bulundurulmalı (Adcock, 2011, s. 21), farklı yaş grubundaki çocukların bakımı için uygun tuvalet ve bebek bezi değiştirme olanaklarını içeren sıhhi alanlara sahip olmaya dikkat edilmeli (IFLA, 2007) ve lamba düğmeleri, prizler gibi teknolojik gereçlerin çocuk güvenliği açısından 
risk teşkil etmemesi (KYGM, 2017b) sağlanmalıdır. Bunun yanında gerçekleştirilen bu çalışma kapsamında güvenlik donanımı bakımından incelenen yedi kütüphanenin yalnızca birinde mobilyaların çocuklar için tehlike arz etmediği bulgusuna ulaşılmıştır. Yapılan bu çalışmanın bulgusuyla paralel olarak Saydam ve Sağlk (2015, s. 68) incelediği halk ve çocuk kütüphaneleri mobilyalarının \%47'sinin kullanıcı için olumsuz ortam oluşturduğu sonucuna ulaşmıştır. Fakat iyi mobilyalar, zihinde o yapıya ilişkin olumlu bir algı yaratıp bulunulan ortamdaki hazzı artırır. $\mathrm{Bu}$ nedenle çocuk kütüphaneleri için seçilecek mobilyaların çocuk merkezli olması şarttır (Y1lmaz, 2019, s. 29). Ayrıca çocuk kütüphaneleri için elzem özelliklerden olan yıldırımsavar (KYGM, 2017b), acil durum bilgi kitapçı̆̆ı ve kaygan olmayan merdiven basamakları (KYGM, 2017b; Yılmaz, 2019) incelenen yedi kütüphanenin yalnızca birinde gözlemlenmiştir. $\mathrm{Bu}$ noktada Ankara'daki çocuk kütüphanelerinin güvenlik donanımı bakımından çoğunlukla yetersiz durumda olduğu ortaya çıkmaktadır. Alan yazında bu çalışmanın bulgularını destekleyecek şekilde Ankara' da (Y1lmaz, 2014, s. 128) ve İstanbul'daki (Kakırman Yıldız, Yalçınkaya ve Saydam, 2018; Saydam ve Sağlık, 2015, s. 73) kütüphanelerin bina özellikleri bakımından yetersiz ve uluslararası standartlardan hayli uzak olduğu bulgusuna ulaşan çalışmalar mevcuttur.

$\mathrm{Bu}$ çalışma kapsamında çocuk kütüphanelerinde değerlendirilen bir diğer unsur ise kütüphanelerin malzeme özellikleridir. IFLA 0-18 yaş grubundaki çocuklar için kütüphane hizmetleri rehberine (2018) göre çocuk kütüphaneleri din, ırk, kültür, cinsiyet, fiziksel veya zihinsel beceri ayırt etmeksizin tüm çocuklar için hizmet sağlamalıdır. Kütüphanelerin bu misyonunun malzeme özelliklerine yansıması istenen bir durumdur. Fakat bu çalışma kapsamında incelenen yedi kütüphanenin yalnızca birinin kullanıcıları için toplumdaki kültürel çeşitliliği sergileyici materyale erişim sağladığı gözlemlenmiştir. Benzer şekilde Kakırman Yıldız, Yalçınkaya ve Saydam'ın (2018, s. 1830) incelediği otuz çocuk kütüphanesinin yalnızca üçünün kültürel faaliyetler sunduğu bulgusuna ulaşmıştır. Oysa kütüphaneler toplumdaki kültürel çeşitliliği sunan materyalleri bulundurulmalıdır (KYGM, 2017a; KYGM, 2017b). Ayrıca bu araştırma sonucunda incelenen tüm kütüphanelerin ödünç alma masası, personel masası, fotokopi ve tarayıcı makinelerinin bulunduğu gözlemlenmiştir. KYGM'ye (2017b) göre kütüphanelerde tarayıcı ve fotokopi makinesi, çocukların boyuna uygun olarak tasarlanmalı ve kullanıcılara danışma, ödünç alma/ iade etme hizmetleri sunacak bir servis bankosu bulunmalıdır. Dolayısıyla bu özelliklerin Ankara'da incelenen kütüphanelerin tamamında bulunması olumlu bir durumdur. Fakat içinde yaşadığımız bilgi toplumunda kütüphanelerin; dijital, akıllı, bilgili ve yaratıcı alt yapılarıyla önemli bir rol oynadığı (Mainka, Hartmann, Orszullok, Peters, Stallmann ve Stock, 2013, s. 295) gerçeği göz önünde bulundurulduğunda ödünç alma masası, personel masası, tarayıcı ve fotokopi makinesi gibi malzemeler gerekli olmakla beraber yeterli olmayabilir. Çalışmanın kütüphanelerin malzeme özelliklerine dair ulaştı̆̆ 1 bir diğer bulgu ise kütüphanelerin yalnızca ikisinin çocukların kullanımı için uygun bilgisayara ve çok dilli görsel-işitsel materyale sahip olduğudur. Bu noktada Ankara'daki kütüphanelerin toplumdaki kültürel çeşitliliği sergileyici materyal, çocukların kullanımı için uygun bilgisayar ve çok dilli görsel-işitsel materyal yönünde eksikliği olduğu ortaya çıkmaktadır. Oysa alan yazın; kütüphanelerin çocukların istediği ve ihtiyaç duyduğu materyallere, bilgisayar ve internete eşit şekilde ulaşmasını garanti altına almak zorunda olduğunu göstermektedir (Frostick, 2009, s. 37). 
Ankara'daki Halk Kütüphanesi Çocuk Bölümleri ve Çocuk Kütüphanelerinin Bina, Güvenlik Donanımı ve Malzeme Niteliklerinin İncelenmesi

Investigation of Building, Security Equipment and Material Qualifications of Public Library Children's

Nihayetinde çalışmada yer alan halk kütüphanelerinin çocuk bölümleri ve çocuk kütüphaneleri tüm özellikler dikkate alınarak (bina, güvenlik donanımı, malzeme özellikleri) değerlendirildiğinde gözlemlenen kütüphanelerin çoğunun ortalamanın altında niteliğe sahip olduğu görülmektedir. Bu bulgunun birden fazla nedeni olabilir. Birincisi kütüphane binalarının başka bir amaç için yapılmış ve sonradan çocuk kütüphanesine veya çocuk bölümüne dönüştürülmüş olmasıdır. Aslında kütüphaneler planlanırken, yörenin ihtiyaçları göz önünde bulundurularak, estetik ve çevre ile bütünleşen projeler geliştirilmeli (KYGM, 2017b) ve çocuklara hizmet verecek kütüphaneler tarafindan mutlaka çocukların gelişim özellikleri, yaşı ve içinde bulundukları toplumun özellikleri dikkate alınmalıdır (Yılmaz, 2019). Yapılan bir çalışmada çocuklar tarafından kütüphanelerin kolay ulaşılabilir, grup çalışmalarına ve oyun oynamaya imkân sağlayan mekânlar olarak algılandığı ortaya çıkarılmıştır (Önal, 2009). Bu çalışma kapsamında değerlendirilen kütüphaneler arasında en az yeterli özellik gösteren Cebeci Halk Kütüphanesinin çocuk bölümünün sonradan açılmış olduğu görülmektedir (T.C. Kültür ve Turizm Bakanlığı, 2021c). Genel olarak değerlendirildiğinde kütüphanelerin çoğunun ortalamanın altında niteliğe sahip olmasındaki bir diğer neden ise kütüphanelere ayrılan bütçe miktarı olabilir. Kütüphanelere ayrılan bütçe miktarı oldukça önemlidir. Çünkü alan yazında kütüphane bütçesinin kesilmesinin uzun vadede ülkelerin ekonomik üretkenliğini olumsuz etkileyeceği iddia edilmektedir (Liu, 2004, s. 435). Ayrıca Çek Cumhuriyeti’nde yapılan bir çalışma, çocuk kütüphane hizmetlerinin etkililiğinin yatırılan her bir birim için 11.2 birim olduğu bulgusuna dikkat çekmiştir (Stejskal, Hájek ve Řehák, 2019). Diğer yandan kütüphanelerin niteliğini etkileyebilecek olduğu düşünülen üçüncü unsur ise kütüphane personelidir. Kütüphaneciler, çocuk gelişimi ve eğitimi hakkında bilgiye ve bu gruptaki çocuklara, ailelerine ve bakıcılarına yönelik en iyi ortamın oluşturulması için planlama becerilerine sahip olmalıdırlar (IFLA, 2007). Ayrıca kütüphaneciler, kütüphane mekânlarının organizasyonuna ilişkin gerekli bilgiler ile donanmalı ve kütüphane organizasyonundaki yadsınamaz rollerini üstlenmelidirler (Öz, 1996, s. 119).

\section{Sonuç ve Öneriler}

$\mathrm{Bu}$ çalışmada, Ankara İl Halk Kütüphanesi ve ilçe halk kütüphanelerine bağlı çocuk bölümlerinin ve Ali Dayı Çocuk Kütüphanesinin bina özelliği, güvenlik donanımı ve malzeme özellikleri incelenmiştir. Bu bağlamda çalışmanın hipotezinin desteklenmesi bakımından genel olarak bakıldığında çalışma kapsamında incelenen kütüphanelerin malzeme özelliği bakımından daha iyi durumdayken bina özelliği bakımından ortalama seviyede bulunduğu ve güvenlik donanımı bakımından çoğunlukla yetersiz durumda olduğu bulgusuna ulaşılmıştır.

Çalışmada yer alan tüm kütüphanelerin; ulaşım ağlarına yakın yerde olması, yeterli ve doğru 1şık alması, uygun oda sıcaklığına sahip olması, acil durumlar için gerekli kurumlara yakın olması, binalarda nem, küf, böcek vb. bulunmaması ve kütüphanede kullanılmayan malzemeler için depo bulunması, yangın tüpü bulunması, çocuklar için ödünç alma masasının bulunması, personel masasının çocukların görebileceği bir noktada olması ve fotokopi ve tarayıc1 makinelerinin bulunması olumlu özellikleridir. Fakat incelenen kütüphanelerin tamamının; bebek bakım odasına sahip olma, yangın söndürme sistemi bulundurma, elektrik prizlerinin kapalı olması ve bakım odasında gerekli hijyenik malzemeler bulundurma özellikleri 
açısından yeniden gözden geçirilmesi gerekmektedir. Çalışmada yer alan her kütüphane için öneriler aşağıda sunulmaktadır.

Ankara Adnan Ötüken İl Halk Kütüphanesi Çocuk Bölümü; kitapların yerini ya da özel alanlarını gösteren sembollerin bulunduğu ve acil toplanma merkezi olan iki kütüphaneden biri olmasının yanı sıra diğer kütüphanelerden farklı olarak yıldırımsavar bulundurması açısından ayırt edici olumlu yönlere sahiptir. Fakat bu kütüphanenin özellikle misafirler için araç otoparkı, lavabo zeminleri ve kafeterya özelliklerini içeren bina özellikleri boyutunda çocuk sayısı ile orantılı sayıda kullanılabilecek hijyenik minderler, toplumdaki kültürel çeşitliliği sergileyici materyaller (kitap, oyuncak, CD vb.) ve ebeveyn odasında ebeveynlere yönelik kitapları içeren malzeme özellikleri boyutunda; kaygan olmayan merdiven basamakları ve çocuklar için tehlike arz etmeyen mobilyaları içeren güvenlik donanımı boyutunda yeniden elden geçirilmesi önerilir.

Ankara Ali Dayı Çocuk Kütüphanesi, diğer hiçbir kütüphanede gözlemlenmeyen özelliklerden; çocukların boylarına uygun ve çocukların kaymayacağı şekilde zemine, kaygan olmayan merdiven basamaklarına, çocuklar için tehlike arz etmeyen mobilyalara, çocuk sayısı ile orantılı sayıda kullanılabilecek hijyenik minderlere ve mevcut ve ulaşılabilir durumda olan acil durum bilgi kitapçığına sahip olması açısından olumlu yönlere sahiptir. Diğer yandan bu kütüphanenin geliştirmesi gereken kullanıcıların ihtiyaçlarını karşılayabilecek bir kafeterya, kullanıcılar ve misafirler için araç otoparkı özelliklerini içeren bina özellikleri boyutu; yıldırımsavar, acil durum bilgi kitapçığı özelliklerini içeren güvenlik donanımı boyutu; toplumdaki kültürel çeşitliliği sergileyici materyaller (kitap, oyuncak, CD vb.) ve ebeveyn odasında ebeveynlere yönelik kitapları içeren malzeme özellikleri boyutu vardır.

Altındağ İlçe Halk Kütüphanesi Çocuk Bölümü, tüm boyutlarda (bina özellikleri, güvenlik donanımı ve malzeme özellikleri) ortalama puana sahiptir. Fakat kullanıcıların ihtiyaçlarını karşılayabilecek bir kafeterya, kullanıcılar ve misafirler için araç otoparkı, çocukların boylarına uygun ve çocukların kaymayacağı şekilde zemine sahip olan lavabolar açısından bina özellikleri boyutunda; yıldırımsavar, acil durum bilgi kitapçığı, kaygan olmayan merdiven basamakları ve çocuklar için tehlike arz etmeyen mobilyalar açısından güvenlik donanımı boyutunda; çocuk sayısı ile orantılı sayıda kullanılabilecek hijyenik minderler, toplumdaki kültürel çeşitliliği sergileyici materyaller (kitap, oyuncak, CD vb.) ve ebeveyn odasında ebeveynlere yönelik kitaplar açısından malzeme özellikleri boyutunda geliştirilmesi gerekmektedir.

Cebeci Halk Kütüphanesi Çocuk Bölümünün tüm boyutlarda (bina özellikleri, malzeme özellikleri ve güvenlik donanımı) yetersiz puanı vardır ve geliştirilmesi gerekmektedir. Özellikle diğer kütüphaneler ile karşılaştırıldığında yalnızca Cebeci Halk Kütüphanesi Çocuk Bölümünde bulunmadığı gözlemlenen; çocukların fiziksel gelişim düzeylerine uygun masalar, çocukların güvenli bir şekilde kullanabileceği sandalyeler açısından bu kütüphanenin yeniden düzenlenmesi önerilmektedir. Ayrıca kullanıcıların ihtiyaçlarını karşılayabilecek bir kafeterya, kullanıcılar ve misafirler için araç otoparkı, çocukların boylarına uygun ve çocukların kaymayacağı şekilde zemine sahip olan lavabolar açısından bina özellikleri boyutu; yıldırımsavar, acil durum bilgi kitapçığı, kaygan olmayan merdiven basamakları ve çocuklar için tehlike arz etmeyen mobilyalar açısından güvenlik donanımı boyutu; çocuk sayısı ile orantılı sayıda kullanılabilecek hijyenik minderler, toplumdaki kültürel çeşitliliği sergileyici 
Ankara'daki Halk Kütüphanesi Çocuk Bölümleri ve Çocuk Kütüphanelerinin Bina, Güvenlik Donanımı ve Malzeme Niteliklerinin İncelenmesi

Investigation of Building, Security Equipment and Material Qualifications of Public Library Children's

materyaller (kitap, oyuncak, CD vb.) ve ebeveyn odasında ebeveynlere yönelik kitaplar açısından malzeme özellikleri boyutu kütüphanenin geliştirmesi gereken özelliklerindendir.

Keçiören Cemil Meriç İlçe Halk Kütüphanesi diğer kütüphanelerde bulunmayan özelliklerden olan misafirler için araç otoparkı, kullanıcıların ihtiyaçlarını karşılayabilecek kafeterya ve toplumdaki kültürel çeşitliliği sergileyici materyalleri (kitap, oyuncak, CD vb.) bulundurması açısından ayırt edici olumlu yönlere sahiptir. Fakat çocukların boylarına uygun ve çocukların kaymayacağı şekilde zemine sahip olan lavaboları içeren bina özellikleri boyutunda; yıldırımsavar, acil durum bilgi kitapçığı, kaygan olmayan merdiven basamakları ve çocuklar için tehlike arz etmeyen mobilyaları içeren güvenlik donanımı boyutunda; çocuk sayısı ile orantılı sayıda kullanılabilecek hijyenik minderler ve ebeveyn odasında ebeveynlere yönelik kitapları içeren malzeme özellikleri boyutunda bu kütüphanenin yeniden elden geçirilmesi önerilir.

Mamak İlçe Halk Kütüphanesi Çocuk Bölümünün tüm boyutlarda (bina özellikleri, güvenlik donanımı ve malzeme özellikleri) ortalama puanları vardır. Fakat bu kütüphanenin, kullanıcıların ihtiyaçlarını karşılayabilecek bir kafeterya, kullanıcılar ve misafirler için araç otoparkı, çocukların boylarına uygun ve çocukların kaymayacağı şekilde zemine sahip olan lavabolar açısından bina özellikleri boyutunda; yıldırımsavar, acil durum bilgi kitapçığı, kaygan olmayan merdiven basamakları ve çocuklar için tehlike arz etmeyen mobilyalar açısından güvenlik donanımı boyutunda; çocuk sayısı ile orantılı sayıda kullanılabilecek hijyenik minderler, toplumdaki kültürel çeşitliliği sergileyici materyaller (kitap, oyuncak, CD vb.) ve ebeveyn odasında ebeveynlere yönelik kitaplar açısından malzeme özellikleri boyutunda geliştirilmesi gerekmektedir.

Sincan İlçe Halk Kütüphanesi Çocuk Bölümünün bina özellikleri güvenlik donanımı ve malzeme özellikleri bakımından ortalamanın altında puanı vardır. Özellikle diğer kütüphaneler ile karşılaştırıldığında yalnızca Sincan İlçe Halk Kütüphanesi Çocuk Bölümünde bulunmadığı gözlemlenen; ilk yardım seti ve ilan panosu özellikleri açısından bu kütüphanenin önlem alması ve yeniden düzenlenmesi önerilmektedir. Bunun yanında kullanıcıların ihtiyaçlarını karşılayabilecek bir kafeterya, kullanıcılar ve misafirler için araç otoparkı, çocukların boylarına uygun ve çocukların kaymayacağı şekilde zemine sahip olan lavabolar açısından bina özellikleri boyutu; yıldırımsavar, acil durum bilgi kitapçığı, kaygan olmayan merdiven basamakları ve çocuklar için tehlike arz etmeyen mobilyalar açısından güvenlik donanımı boyutu; çocuk sayısı ile orantılı sayıda kullanılabilecek hijyenik minderler, toplumdaki kültürel çeşitliliği sergileyici materyaller (kitap, oyuncak, CD vb.) ve ebeveyn odasında ebeveynlere yönelik kitaplar açısından malzeme özellikleri boyutu kütüphanenin geliştirmesi önerilen özelliklerindendir.

Her bilimsel çalışmada olduğu gibi bu çalışmada da çeşitli sınırlılıklar mevcuttur. Ankara İl Kültür ve Turizm Müdürlüğüne bağlı 43 halk ve 1 çocuk kütüphanesinden sadece 6 halk kütüphanesi ve 1 çocuk kütüphanesi bu çalışmada yer almış ve dolayısı ile bu sayı ile Ankara'da bulunan halk kütüphanelerine yönelik bir genelleme yapılmamış olup çalışmada yer alan kütüphaneler özelinde çıkarımlar yapılmıştır. Diğer taraftan halk kütüphanelerinin fiziksel özelliklerine yönelik yapılacak çalışmalarda Kütüphaneler ve Yayımlar Genel Müdürlüğü Kütüphane Planlama Şube Müdürlüğünün yaptığı çalışmalar ve yöneticilerin görüşlerinin 
alınması çalışmaların kapsayıcılığını artırarak farklı görüş ve öneriler içermesi bakımından önerilmektedir.

Sonuç olarak kütüphaneler; bina özellikleri, güvenlik donanımı ve malzeme özellikleri bakımından bir bütün olarak ele alınmalı ve bu üç özellik dikkate alınarak kütüphanenin fiziki ve teknolojik alt yapı desteğiyle toplumun günlük ihtiyaçlarına cevap verebilecek şekilde tasarlanmasını destekleyecek niteliklerle bütünleştirilmelidir. Ayrıca kütüphaneler ulusal ve uluslararası standartlar göz önünde bulundurularak ve çağın gereksinimlerini dikkate alarak tasarlanmalıdır. Böylece çocuklar için bilgiye kolayca erişebilecekleri, bilgi okuryazarlı̆̆ geliştirebilecekleri ve yaşam boyu öğrenmeye motive olabilecekleri güvenli bir ortam sağlanacaktır.

\section{Teşekkür}

$\mathrm{Bu}$ çalışma kapsamında oluşturulan kontrol listesine ilişkin bizimle görüşlerini paylaşarak çalışmamıza katkıda bulunan değerli alan uzmanlarına sonsuz teşekkür ederiz. Bunun yanında çalışmanın başlangıç aşamasında izin alma sürecinde verdiği destekler için Ankara Adnan Ötüken İl Halk Kütüphanesi Müdürü Ahmet Çakmak'a ve kütüphaneci Eren Cem Koç'a teşekkür ederiz. Ayrıca gittiğimiz her kütüphanede bize hoşgörü ve saygı ile yaklaşan, çalışmamızı gerçekleştirebilmemiz için elinden gelen desteği sağlayan değerli kütüphanecilere ve diğer kütüphane personeline teşekkürü borç biliriz.

\section{Kaynakça}

Adcock, E. P. (2011). Kütüphane malzemesinin bakım ve kullanımında IFLA ilkeleri (Ş. N. Somer, Çev.). https://www.ifla.org/files/assets/pac/ipi/ipil-tr.pdf

Adnan Ötüken Halk Kütüphanesi. (2021). Beşikkaya Mahallesi’ndeki kütüphanenin açılışına çok sayıda davetli katıldl. http://www.adnanotukenkutup.gov.tr/yazdir?5D3A6FF4BDC8BE988BF0BD072355EF7B

AIA. (2021). 2021 AIA/ALA library building awards. https://www.aia.org/resources/6392704-2021aiaala-library-building-awards

Aldemir, A. (2018). Türkiye'de çocuk odaklı halk kütüphaneciliği hizmetleri [Bildiri]. 1. Uluslararası Çocuk Kütüphaneleri Sempozyumu Bildirileri, 14-17 Kasım 2018, Nevşehir, Türkiye (ss. 33-41) içinde. $\quad$ https://kygm.ktb.gov.tr/Eklenti/63324,1-uluslararasi-cocuk-kutuphanelerisempozyumupdf.pdf?0

Bossaller, J., Oprean, D., Urban, A. ve Riedel, N. (2020). A happy ambience: Incorporating ba and flow in library design. The Journal of Academic Librarianship, 46(6), 102228.

Bradfield, N. (2011). Early childhood education and child development for elementary school librarians.

https://citeseerx.ist.psu.edu/viewdoc/download?doi=10.1.1.1030.534\&rep=rep1\&type=pdf

Burkut, E. B. (2018). Çocuk (lar) ve mekân (lar): Çocuk kütüphanelerinin mekânsal tasarım süreci ve analizi [Bildiri]. 1. Uluslararası Çocuk Kütüphaneleri Sempozyumu Bildirileri, 14-17 Kasım 2018, Nevşehir, Türkiye (ss. 163-186) içinde. https://kygm.ktb.gov.tr/Eklenti/63324,1uluslararasi-cocuk-kutuphaneleri-sempozyumupdf.pdf?0

Cevher, N. (2015). Ankara'daki halk kütüphanesi çocuk bölümlerinin çocukların okuma alışkanlığındaki rolü [Yayımlanmamış yüksek lisans tezi]. Hacettepe Üniversitesi.

Cohen, L., Manion, L. ve Morrison, K. (2000). Research methods in education (5. bs.). Routledge Falmer. 
Ankara’daki Halk Kütüphanesi Çocuk Bölümleri ve Çocuk Kütüphanelerinin Bina, Güvenlik Donanımı ve Malzeme Niteliklerinin İncelenmesi

Investigation of Building, Security Equipment and Material Qualifications of Public Library Children's Departments and Children's Libraries in Ankara 431

Coughlan, M., Cronin, P. ve Ryan, F. (2009). Survey research: Process and limitations. International Journal of Therapy and Rehabilitation, 16(1), 9-15. https://doi.org/10.12968/ijtr.2009.16.1.37935

Çakın, İ., Ersoy, O., Çelik, H. ve Duman, H. (1993). Türk kütüphaneciliğinin sorunları ve çözüm önerileri. Türk Kütüphaneciliği, 7(3), 220-226.

Delice Güller, E. ve Bilbay, P. (2016). Kütüphane yapılarında okul öncesi çocuklara yönelik interaktif mekânların irdelenmesi. Türk Kütüphaneciliği, 30(3), 398-414.

Fasick, A. M. ve Edmonds, L. (2013). Managing children's services in libraries (4. bs.). Libraries Unlimited.

Fraenkel, R., Wallen, E. ve Hyun, H. (2012). How to design and evaluate research in education (8. bs.). The McGraw-Hill Companies.

Frostick, C. M. (2009). The myth of equal access. Children \& Libraries, 7(3), 32-41.

Goodwin, L. D. (2001). Interrater agreement and reliability. Measurement in Psychical Education and Exercises Science, 5(1), 13-34.

Goulding, A., Dickie, J. ve Shuker, M. J. (2017). Observing preschool storytime practices in Aotearoa New Zealand's urban public libraries. Library \& Information Science Research, 39(3), 199-212.

Gönen, M., Temiz, N. ve Akbaş, S. C. (2015). Erken çocukluk döneminde çocuk kütüphanelerinin rolü ve önemi: Bir kütüphane programı örneği. Milli Ĕ̆itim Dergisi, 45(208), 76-89.

International Federation of Library Associations and Institutions [IFLA]. (2003). Çocuk kütüphanesi hizmetleri için ilkeler (B. Yılmaz ve S. Ekici, Çev.). https://www.ifla.org/files/assets/libraries-forchildren-and-ya/publications/guidelines-for-childrens-libraries-services-tr.pdf

International Federation of Library Associations and Institutions [IFLA]. (2006). Guidelines for children's library services. https://www.ifla.org/files/assets/libraries-for-children-andya/publications/guidelines-for-childrens-libraries-services-en.pdf

International Federation of Library Associations and Institutions [IFLA]. (2007). Guidelines for library services to babies and toddlers. http://www.ifla.org/files/assets/hq/publications/professionalreport/100.pdf

International Federation of Library Associations and Institutions [IFLA]. (2009). Çok-kültürlü topluluklar: Kütüphane hizmetleri kllavuzu (G. Demir, Çev.). https://www.ifla.org/files/assets/library-services-to-multiculturalpopulations/publications/multicultural-communities-tr.pdf

International Federation of Library Associations and Institutions [IFLA]. (2015). IFLA okul kütüphaneleri rehberi (S. Arığlu ve A. Yüksel Durukan, Çev.). https://www.ifla.org/files/assets/school-libraries-resource-centers/publications/ifla-schoollibrary-guidelines-tr.pdf

International Federation of Library Associations and Institutions [IFLA]. (2018). IFLA 0-18 yaş grubundaki çocuklar için kütüphane hizmetleri rehberi (C. Polat, E. B. Eroğlu, S. Çuhadar, A. Kavak ve B. Tan, Çev.). https://www.ifla.org/files/assets/libraries-for-children-andya/publications/ifla-guidelines-for-library-services-to-children_aged-0-18-tr.pdf

Kakırman Yıldız, A., Yalçınkaya, B. ve Saydam, V. (2018). İstanbul'daki halk kütüphanelerinin okul öncesi dönem çocuklara uygunluğunun değerlendirilmesi. DTCF Dergisi, 58(2), 1811-1836.

Kelley, K., Clark, B., Brown, V. ve Sitzia, J. (2003). Good practice in the conduct and reporting of survey research. International Journal for Quality in Health Care, 15(3), 261-266. https://doi.org/10.1093/intqhe/mzg031

Keseroğlu, H. S. (2010). Kütüphanenin değişen mimarisi. Mimar.ist: 3 Aylık Mimarlık Kültürü Dergisi, 10(37), 46-54. 
Kipfer, K. (2019). Starting early: A revised early literacy strategy. ALSC: Association for Library Service to Children, 17(1), 3-4. https://dx.doi.org/10.5860/cal.17.1.3

Koh, E. T. ve Owen, W. L. (2000). Descriptive research and qualitative research. Introduction to Nutrition and Health research (ss. 219-248) içinde. Springer. https://doi.org/10.1007/978-14615-1401-5_12

Kupetz, B. N. (1993). A shared responsibility: Nurturing literacy in the very young. School Library Journal, 39(7), 28-31.

Küçükcan, B. (2010). Bilgiyi toplama mekânı: Kütüphane binaları. Mimar.ist: 3 Ayllk Mimarlık Kültürü Dergisi, 10(37), 55-59.

Kütüphaneler ve Yayımlar Genel Müdürlüğü [KGYM]. (2017a). Çocuk Kütüphaneleri Çalıştayı. C. Polat, E. Yılmaz ve A. Kakırman Yıldız (Yay. Hazl.). Kütüphaneler ve Yayımlar Genel Müdürlüğü.

Kütüphaneler ve Yayımlar Genel Müdürlüğü [KGYM]. (2017b). Halk Kütüphanelerinde Mimari Uygulamalar Çalıştayı. A. H. Kuzucuoğlu, B. B. Yılmaz ve M. Yavuzdemir (Yay. Hazl.). Kütüphaneler ve Yayımlar Genel Müdürlüğü.

Landis, J. R. ve Koch, G. (1977). The measurement of observer agreement for categorical data. Biometrics, 33, 159-174.

Lawshe, C. H. (1975). A quantitative approach to content validity. Personnel Psychology, 28, 563-575.

Liu, L. G. (2004). The contribution of public libraries to countries' economic productivity: A path analysis. Library Review, 53(9), 435-441.

Mainka, A., Hartmann, S., Orszullok, L., Peters, I., Stallmann, A. ve Stock, W. G. (2013). Public libraries in the knowledge society: Core services of libraries in informational world cities. Libri, 63(4), 295-319.

Miller, C., Zickuhr, K., Rainie, H. ve Purcell, K. (2013). Parents, children, libraries, and reading. https://core.ac.uk/download/pdf/30676931.pdf

Mills, J. E., Romeign Stout, E., Campbell, C. ve Koester, A. (2015). Results from the young children, new media, and libraries survey: What did we learn? Children and Libraries, 13(2), 26-32.

Ozanne, L. K. ve Ozanne, J. L. (2011). A child's right to play: The social construction of civic virtues in toy libraries. Journal of Public Policy \& Marketing, 30(2), 264-278.

Önal, İ. (2009). Designing tomorrow's libraries with children's views. World Library and Information Congress: 75th IFLA General Conference and Council, 23-27 August 2009, Milan, Italy. https://citeseerx.ist.psu.edu/viewdoc/download?doi=10.1.1.150.8885\&rep=rep1\&type=pdf

Öz, Z. O. (1996). Kütüphanelerin mekânsal organizasyonunda kütüphanecinin rolü. Türk Kütüphaneciliği, 10(2), 119-136.

Pivik, J. R. (2010). The perspective of children and youth: How different stakeholders identify architectural barriers for inclusion in schools. Journal of Environmental Psychology, 30(4), 510517.

Potur, A. A. (2010). Sessizlikten oyunlaşan mekânlara: Özgürleştiren öğrenme ortamları olarak çocuk kütüphaneleri. Mimar.ist: 3 Aylık Mimarlık Kültürü Dergisi, 10(37), 74-79.

Saydam, V. ve Sağlik, Ö. (2015). İstanbul'daki Kültür ve Turizm Bakanlığına bağl1 halk ve çocuk kütüphanelerinin iç ve dış mekân açısından incelenmesi. Milli Eğitim Dergisi, 208(44), 61-75.

Sezgin Selçuk, G. (2018). Tarama yöntemi. H. Özmen ve O. Karamustafaoğlu (Yay. Hazl.). Eğitimde araştırma yöntemleri (2. bs.) (ss. 140-161) içinde. Pegem Akademi.

Shine Edizer, F. ve Akçay Duff, E. R. (2019). How an intentionally inviting play library benefits young children and the community. Journal of Invitational Theory and Practice, 25, 14-24. 
Ankara'daki Halk Kütüphanesi Çocuk Bölümleri ve Çocuk Kütüphanelerinin Bina, Güvenlik Donanımı ve Malzeme Niteliklerinin İncelenmesi

Investigation of Building, Security Equipment and Material Qualifications of Public Library Children's

Stejskal, J., Hájek, P. ve Řehák, T. (2019). The economic value of library services for children: The case of the Czech public libraries. Library \& Information Science Research, 41(3), 100963.

Stevens, N. D. (1999). Librarians and Libraries for Children. The Library Quarterly, 69(1), 90-93.

Sullivan, M. (2005). Fundamentals of children's services. American Library Association.

T.C. Kültür ve Turizm Bakanlı̆̆ı. (2021a). Adnan Ötüken Il Halk Kütüphanesi: Kütüphanemiz. https://adnanotuken.kutuphane.gov.tr/TR-197301/-kutuphanemiz.html

T.C. Kültür ve Turizm Bakanlığı. (2021b). Ankara Ali Dayı Çocuk Kütüphanesi. https://alidayicocuk.kutuphane.gov.tr/

T.C. Kültür ve Turizm Bakanlığı. (2021c). Ankara Cebeci Halk Kütüphanesi. https://cebeci.kutuphane.gov.tr/

T.C. Kültür ve Turizm Bakanlığı. (2021d). Kütüphaneler ve Yayımlar Genel Müdürlüğ̈̈. Keçiören Cemil Meriç İlçe Halk Kütüphanesi açılışı basın duyurusu. https://kygm.ktb.gov.tr/TR91950/kecioren-cemil-meric-ilce-halk-kutuphanesi-acilisi-basi-.html

T.C. Kültür ve Turizm Bakanlığı. (2021e). Mamak İlçe Halk Kütüphanesi. https://mamak.kutuphane.gov.tr/

T.C. Kültür ve Turizm Bakanlığı. (2021f). Sincan İlçe Halk Kütüphanesi. https://sincan.kutuphane.gov.tr/TR-155362/kutuphanemiz-hakkinda.html

Veneziano L. ve Hooper, J. (1997) A method for quantifying content validity of health-related questionnaires. American Journal of Health Behavior, 21(1), 67-70.

Von Eye, A. ve Mun, E. Y. (2005). Analyzing rater agreement: Manifest variable methods. Lawrence Erlbaum Associates.

Yavuz Öden, H. (2021). Çocuk kütüphanesi iç mekân tasarımında çok fonksiyonlu mobilyaların kullanımı. Online Journal of Art and Design, 9(3), 92-103.

Yılmaz, A. (2008). Okul öncesi çocuklara yönelik kütüphane hizmetlerinin önemi ve başarılı bir kütüphane örneği. Türk kütüphaneciliği, 22(2), 169-186.

Y1lmaz, B. (2014). Ankara' da halk kütüphanesi sistemi: Niceliksel bir değerlendirme. Ankara Araştırma Dergisi, 2(2), 115-130.

Y1lmaz, B. (2019). Çocuk kütüphanesi hizmetleri kılavuzu. Hiperlink.

Yurdugül, H. (2005). Ölçek geliştirme çalışmalarında kapsam geçerlik indekslerinin kullanılması. [Bildiri]. XIV. Ulusal Eğitim Bilimleri Kongresi, 28-30 Eylül 2005, Denizli (ss. 1-6) içinde. http://yunus.hacettepe.edu.tr/ yurdugul/3/indir/PamukkaleBildiri.pdf

\section{EK-1 Çocuk Kütüphaneleri Fiziksel Durum Kontrol Listesi KG Oranları}

\begin{tabular}{|l|l|l|}
\hline Bina Özellikleri & Gerekli & $\begin{array}{l}\text { KGO } \\
\text { oranları }\end{array}$ \\
\hline 1. Bebek bakım odası vardır. & 10 & 0.66 \\
\hline 2. Yerler yumuşak zemindir. & 12 & 1 \\
\hline $\begin{array}{l}\text { 3. Yerler kaygan değildir. } \\
\text { 4. Kütüphane binasında özel gereksinimli bireyler için } \\
\text { rampa/asansör vardır. }\end{array}$ & 12 & 1 \\
\hline 5. Lavabolar çocukların boylarına uygundur. & 12 & 1 \\
\hline
\end{tabular}




\begin{tabular}{|c|c|c|}
\hline 6. Lavabo zeminleri çocukların kaymayacağı şekildedir. & 12 & 1 \\
\hline 7. Mobilyalar ve dekorasyon çocukların yaş grubuna uygundur. & 11 & 0.83 \\
\hline 8. Sessiz alanlar kadar sesli alanlar vardır. & 9 & 0.5 \\
\hline 9. Ulaşım ağlarına yakın yerdedir. & 11 & 0.83 \\
\hline 10. Bebek arabasının kullanılabileceği rampa ya da asansör vardır. & 11 & 0.83 \\
\hline 11. Belirli alanlarda kolay temizlenebilir zemin vardır. & 10 & 0.66 \\
\hline 12. Yeterli ve doğru ışık almaktadır. & 10 & 0.66 \\
\hline $\begin{array}{l}\text { 13. Sesli ve sessiz alanlar birbirini etkilemeyecek şekilde } \\
\text { konumlandırılmıştır. }\end{array}$ & 12 & 1 \\
\hline 14. Uygun oda sıcaklığ1 sağlanmıştır. & 11 & 0.83 \\
\hline 15. Binada birbirinden bağımsız alanlar arası ulaşım kolaydır. & 12 & 1 \\
\hline $\begin{array}{l}\text { 16. Renklerin tanımlayıcı ve yönlendirici özellikleri göz önünde } \\
\text { bulundurularak dekore edilmiştir. }\end{array}$ & 11 & 0.83 \\
\hline 17. Kullanıcılar ve misafirler için araç otopark1 vardır. & 11 & 0.83 \\
\hline 18. Görevli araç otopark1 vardır. & 10 & 0.66 \\
\hline 19. Acil durumlar için gerekli kurumlara yakındır. & 12 & 1 \\
\hline 20. Ebeveynlerin vakit geçirebileceği açık veya kapalı alanlar vardır. & 11 & 0.83 \\
\hline 21. Kütüphanede kullanılmayan malzemeler için depo vardır. & 9 & 0.5 \\
\hline 22. Binada nem, küf, böcek vb. yoktur. & 11 & 0.83 \\
\hline 23. Nitelikli vakit geçirilebilecek açık alanlar vardır. & 8 & 0.33 \\
\hline \multirow[t]{2}{*}{ 24. Kullanıcıların ihtiyaçlarını karşılayabilecek bir kafeterya vardır. } & 10 & 0.66 \\
\hline & KGİ & 19.1 \\
\hline \multicolumn{3}{|l|}{ Güvenlik Donanımı } \\
\hline $\begin{array}{l}\text { 25. Olası kazaları önlemek için kapı ve cam pervazlarına yönelik } \\
\text { gerekli tedbirler alınmıştır. }\end{array}$ & 12 & 1 \\
\hline $\begin{array}{l}\text { 26. Merdiven boşlukları çocukların güvenliğini tehdit etmeyecek } \\
\text { şekildedir. }\end{array}$ & 12 & 1 \\
\hline 27. Merdiven tırabzanları çocuklar için uygundur. & 12 & 1 \\
\hline 28. Merdiven basamakları kaygan değildir. & 12 & 1 \\
\hline 29. Mobilyalar çocuklar için tehlike arz etmemektedir. & 12 & 1 \\
\hline 30. İlk yardım seti vardır. & 12 & 1 \\
\hline 31. Elektrik prizleri kapalıdır. & 11 & 0.83 \\
\hline 32. Malzeme kenarları keskin değildir. & 10 & 0.66 \\
\hline $\begin{array}{l}\text { 33. Olağanüstü herhangi bir durum için yönlendirici işaret ve gerekli } \\
\text { malzemeler yerleştirilmiştir. }\end{array}$ & 11 & 0.83 \\
\hline 34. Acil toplanma merkezi vardır. & 12 & 1 \\
\hline 35. Isıtıcılar çocukların ulaşamayacağı alandadır. & 12 & 1 \\
\hline 36. Bakım odasında gerekli hijyenik malzemeler vardır. & 10 & 0.66 \\
\hline 37. Acil durum bilgi kitapçığı mevcut ve ulaşılabilir durumdadır. & 10 & 0.66 \\
\hline
\end{tabular}


Ankara’daki Halk Kütüphanesi Çocuk Bölümleri ve Çocuk Kütüphanelerinin Bina, Güvenlik Donanımı ve Malzeme Niteliklerinin İncelenmesi

Investigation of Building, Security Equipment and Material Qualifications of Public Library Children's Departments and Children's Libraries in Ankara

\begin{tabular}{|c|c|c|c|}
\hline 38. Duman, yangın ve su algılama sistemi vardır. & 12 & 1 & \\
\hline 39. Otomatik yangın söndürme sistemi vardır. & 10 & 0.66 & \\
\hline 40. Binada yıldırımsavar vardır. & 10 & 0.66 & \\
\hline 41. Yangın tüpü vardır. & 11 & 0.83 & \\
\hline & KGİ & 14.79 & 0.87 \\
\hline Malzeme & 11 & 0.83 & \\
\hline 42. Raflar çocukların göz hizasındadır. & 10 & 0.66 & \\
\hline $\begin{array}{l}\text { 43. Çocuk sayıs ile orantılı sayıda kullanılabilecek hijyenik } \\
\text { minderler vardır. }\end{array}$ & 12 & 1 & \\
\hline 44. Çocukların fiziksel gelişim düzeylerine uygun masalar vardır. & 12 & 1 & \\
\hline $\begin{array}{l}\text { 45. Çocukların güvenli bir şekilde kullanabileceği sandalyeler } \\
\text { vardır. }\end{array}$ & 11 & 0.83 & \\
\hline $\begin{array}{l}\text { 46. Çocukların yaş gruplarına uygun olarak kullanabileceği çeşitli ve } \\
\text { yeterli sayıda boyalar vardır. }\end{array}$ & 10 & 0.66 & \\
\hline 47. Çocuklar için ödünç alma masası vardır. & 12 & 1 & \\
\hline 48. Yutulabilecek ve tehlikeli olabilecek küçük malzemeler yoktur. & 11 & 0.83 & \\
\hline 49. Çocukların kullanımı için bilgisayarlar vardır. & 12 & 1 & \\
\hline 50. Çok dilli çocuklara uygun görsel-işitsel materyal vardır. & 11 & 0.83 & \\
\hline $\begin{array}{l}\text { 51. Toplumdaki kültürel çeşitliliği sergileyici materyal (kitap, } \\
\text { oyuncak, CD vb.) vardır. }\end{array}$ & 11 & 0.83 & \\
\hline 52. Çocukların gelişim düzeylerine uygun oyuncaklar vardır. & 9 & 0.5 & \\
\hline 53. Personel masası çocukların görebileceği bir noktadadır. & 9 & 0.5 & \\
\hline 54. Projeksiyon aleti vardır. & 9 & 0.5 & \\
\hline 55. Hoparlör vardır. & 11 & 0.83 & \\
\hline 56. Fotokopi ve tarayıcı makinesi vardır. & 7 & 0.16 & \\
\hline 57. İlan panosu vardır. & 9 & 0.5 & \\
\hline 58. Ebeveyn odasında ebeveynlere yönelik kitaplar vardır. & 12 & 1 & \\
\hline 59. Uygun noktalarda güvenlik kameraları vardır. & 12 & 1 & \\
\hline \multirow[t]{3}{*}{ 60. Kitapların yerini ya da özel alanları gösteren semboller vardır. } & 11 & 0.83 & \\
\hline & & 14.46 & 0.761 \\
\hline & \multicolumn{2}{|l|}{ KGİ } & 0.805 \\
\hline
\end{tabular}

